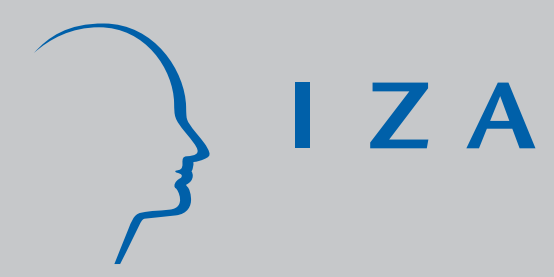

IZADP No. 1962

The Risk-Return Trade-Off in Human Capital Investment

Charlotte Christiansen J uanna Schröter J oensen Helena Skyt Nielsen

February 2006 


\title{
The Risk-Return Trade-Off in Human Capital Investment
}

\author{
Charlotte Christiansen \\ Aarhus School of Business

\section{Juanna Schröter Joensen} \\ University of Aarhus \\ Helena Skyt Nielsen \\ University of Aarhus \\ and IZA Bonn
}

\section{Discussion Paper No. 1962 \\ February 2006}

\author{
IZA \\ P.O. Box 7240 \\ 53072 Bonn \\ Germany \\ Phone: +49-228-3894-0 \\ Fax: +49-228-3894-180 \\ Email: iza@iza.org
}

\begin{abstract}
Any opinions expressed here are those of the author(s) and not those of the institute. Research disseminated by IZA may include views on policy, but the institute itself takes no institutional policy positions.

The Institute for the Study of Labor (IZA) in Bonn is a local and virtual international research center and a place of communication between science, politics and business. IZA is an independent nonprofit company supported by Deutsche Post World Net. The center is associated with the University of Bonn and offers a stimulating research environment through its research networks, research support, and visitors and doctoral programs. IZA engages in (i) original and internationally competitive research in all fields of labor economics, (ii) development of policy concepts, and (iii) dissemination of research results and concepts to the interested public.
\end{abstract}

IZA Discussion Papers often represent preliminary work and are circulated to encourage discussion. Citation of such a paper should account for its provisional character. A revised version may be available directly from the author. 
IZA Discussion Paper No. 1962

February 2006

\section{ABSTRACT}

\section{The Risk-Return Trade-Off in Human Capital Investment ${ }^{*}$}

In this paper we analyze investments in human capital assets in a way which is standard for financial assets, but not (yet) for human capital assets. We study mean-variance plots of human capital assets. We compare the properties of human capital returns using a performance measure and by using tests for mean-variance spanning. A risk-return trade-off is revealed, which is not only related to the length of education but also to the type of education. We identify a range of educations that are efficient in terms of investment goods, and a range of educations that are inefficient, and may be chosen for consumption purposes.

JEL Classification: $\quad 121, \mathrm{~J} 24$

Keywords: educational choice, efficient frontier, human capital investment, mean-variance analysis

Corresponding author:

Helena Skyt Nielsen

Department of Economics

University of Aarhus

Ndr.Ringgade 1

8000 Aarhus C

Denmark

Email: hnielsen@econ.au.dk

\footnotetext{
* We thank the Danish Research Agency for financial support. We appreciate useful comments on earlier versions from Martin Browning, Alan Manning, Annette Vissing-Jørgensen, and Nina Smith, as well as from conference participants at ESPE, EALE, at the workshop 'Education as a Risky Asset' in Aarhus 2003, at seminars at the Aarhus School of Business (Dept. of Finance and Dept. of Economics), at Aarhus University, and at University of Copenhagen. The usual disclaimer applies.
} 


\section{Introduction}

Since the human capital revolution around 1970, economists have viewed education as an investment as well as a consumption good. The standard approach assumes that the individual invests an amount of time in education and then the return shows up in terms of enhanced future earnings. Hence, two individuals with identical abilities and borrowing opportunities would choose identical lengths of education. We extend this standard approach and allow the individual to choose between different educations (of varying length and subject) leading to future income streams with different properties in terms of means, variances, and covariances with the stochastic discount factor. We denote these different investment goods human capital assets. Hence, two individuals with identical abilities and borrowing opportunities might now choose different educations if they differ in terms of utility over risk and return. The main purpose of this paper is to shed more light on the risk-return trade-off in human capital investment as estimated from a rich dataset on individual incomes and education.

Relatively little is known about the properties of human capital returns despite the vast amount of evidence showing the importance of human capital to the structure and evolution of earnings, employment, fertility, and economic growth; see for example Rosen (1987) and Becker (1993) for a review. On top of that, human capital has a dominant position in the aggregate wealth portfolio. Becker (1993) estimates the value of human capital to be three to four times the combined value of stocks, bonds, and other assets. For the largest part of (employed) individuals, human capital is the most important component in their wealth portfolio, since financial assets such as stocks are concentrated in the portfolios of the few; see for example Haliassos and Bertraut (1995) and Christiansen, Joensen and Rangvid (2005) who find that few individuals hold stocks, and that individuals' human capital assets affect the stock market participation decision. On the other hand, even large changes in the market value of financial assets will probably not affect the human capital investment decisions of most individuals. This view is also supported by Becker (1997), who points out that human capital is largely unaffected by financial markets' gyrations.

We treat the human capital market separately from the equity market, since our goal is to compare the human capital assets that an individual can choose between rather than relate investment in human capital assets to investments in financial assets. Treating human capital investments separately from financial investments complies with the early empirical findings that human capital does not influence the findings regarding stock returns in the CAPM framework, cf. Fama and Schwert (1977) and 
Liberman (1980). Newer studies provide contradictory results: Ribeiro (2002) confirms the earlier results because he finds that the dividend growth rate is hardly predictable by the "labor income-dividend" ratio. On the contrary, Santos and Veronesi (2001) find that a time series of aggregate labor income helps predict future stock returns. Likewise, Palacios-Huerta (2003b) tends to contradict the earlier findings. He investigates the effect of human capital in the conditional CAPM framework, and finds that human capital returns help explaining the cross-section of financial asset returns. Furthermore, Palacios-Huerta (2003a) finds that human capital assets have higher return per unit of risk than financial assets. We take no stand in this debate about the interrelationship between returns to human capital and financial assets because we treat human capital investments as separate from financial investments.

There are only few papers that investigate the risk-return trade-off on human capital investments in a fashion similar to ours. Palacios-Huerta (2003c) finds that frictions on human capital markets help explain the risk-adjusted return on human capital. Palacios-Huerta (2003a) uses mean-variance spanning tests to compare the properties of the returns to various human capital assets by comparing the efficient frontier in the mean-variance space spanned by a subset of assets to that spanned by all assets, e.g. human capital assets of white males are compared to those of white males and white females in order to see if the mean-variance trade-off would be more favorable had the choice set been extended. He finds a wide dispersion in the return per unit of risk for different human capital assets.

Like the stock market, the human capital market consists of a wide range of assets, i.e. educations. Each individual chooses the exact asset that matches her preferred combination of risk and return in terms of future income. Our data set comprises 104 different human capital assets that cover a matrix of various topics (e.g. economics) and levels of education (e.g. BA). Studying risk-return plots based on raw log income and Mincer residuals, we find a clear risk-return trade-off, which is not only related to level but also to type of education. The mean-variance plots provide valuable information as to which educations are efficient investment goods and which educations seem to be chosen for other reasons. To our knowledge, showing such meanvariance plots is new to the field of labor economics. Furthermore, we corroborate on our findings by applying an asset performance measure and analyzing the properties of the various human capital returns by testing whether the mean-variance frontiers spanned by different sets of assets coincide. 
The remaining part of the paper is organized as follows. Section 2 presents our approach to the analysis of the risk-return trade-off. Section 3 presents the empirical analysis, whereas section 4 concludes the paper.

\section{Modeling Risk-Return Trade-Off}

\subsection{Traditional Labor Economics Models}

Unlike the finance literature, it is not yet standard to consider risk and uncertainty in studies of return to human capital investments. In human capital theory, education is considered an investment of time plus the direct costs of schooling in exchange for enhanced future earnings prospects; see Becker (1964). The standard Mincer (1974) earnings equation is given as:

$$
\ln W_{i}=\alpha_{0}+\alpha_{1} S_{i}+\alpha_{2} X_{i}+\alpha_{3} X_{i}^{2}+\varepsilon_{i},
$$

where $\varepsilon_{i} \sim N\left(0, \sigma^{2}\right), W_{i}$ denotes wages, $X_{i}$ denotes years of experience, and $S_{i}$ years of schooling.

Some attempts have been made to incorporate uncertainty in the return to schooling within the traditional framework. Empirical evidence suggests that risk is indeed compensated resulting in a positive risk-return trade-off. Harmon, Hogan and Walker (2003) base their studies on random coefficients while distinguishing between the levels of education. Hartog and Vijverberg (2002) estimate risk compensation by use of occupationeducation cells, where education is measured in years. This is a proxy for detailed career choices, but in reality, the occupational choice follows after completion of education. Using education specific cells and applying a range of different risk measures, Diaz-Serrano, Hartog and Nielsen (2003) find a positive risk compensation for both permanent and transitory income shocks. In a cross-country study, Pereira and Martins (2002) estimate the return from equation (1), and the risk is measured as the difference in returns between the $90^{\text {th }}$ and $10^{\text {th }}$ percentile estimates from quantile regressions. The study finds a positive relationship between risk and return across countries. If individuals do not know where they will end up in the conditional income distribution before entering the labor market, this is a good measure of income risk. But since we show that a lot of this income risk is predictable ex-ante by the type of education the individual is holding, this is not an appropriate risk measure from our perspective.

Fuchs-Schündeln and Schündeln (2005) use the German reunification as an example of exogenous reassignment of labor income risk, and find that selfselection of risk averse agents into less risky occupations is non negligible. Chen (2003) also finds that risk averse individuals choose less risky 
education. She finds that the wage variance increases with level of education (high school versus college) when she adjusts the wage variance to take care of the selection bias stemming from heterogeneity in risk aversion.

Because detailed information about education is not available or applied in previous studies, the assumption is that the risk-return properties of human capital investments are directly related to the years (or level) of education. Under that assumption, a cross-sectional risk measure would be severely contaminated due to the fact that subject heterogeneity in addition to other individual heterogeneity is picked up in the risk measure. Say, long educations were found to be more 'risky'. This finding would partly reflect the fact that long educations include both MA/MSc in Philosophy and in Economics, where economists are on average much better paid than philosophers. We apply time-series based risk measures and distinguish between specific human capital assets, meaning that we take into account both the length of education and the subject of specialization. Hence, we avoid that risk measures are contaminated by subject heterogeneity.

\subsection{A Financial Economics Approach to Risk-Return Trade-Off}

In the finance literature, most predominantly in the portfolio selection models, the trade-off between risk and return has been studied extensively. We base our empirical analysis on the mean-variance model of Markowitz (1952) because we find that it is very useful for studying human capital assets. ${ }^{1}$

In the mean-variance world agents base their investment decisions solely on the expected return and variance of their portfolio. Investors prefer higher expected return ceteris paribus and equivalently prefer less risk (variance) ceteris paribus. The mean-variance model applies plots showing the mean return of each asset and all possible portfolios of assets against their standard deviation (denoted mean-variance plots). All feasible investment strategies are contained in the feasible set in the mean-standard deviation space shown in Figure 1. All investors hold portfolios that are located on the efficient frontier, which is the northwestern envelope curve of the feasible set. $^{2}$ Only on the frontier, is it possible to obtain the lowest standard

\footnotetext{
1 The well-known Capital Asset Pricing Model (CAPM) of Sharpe (1964) and Lintner (1965) is a popular generalization of the mean variance model which is often applied to portfolio analysis in financial economics.

${ }^{2}$ We ignore the existence of a risk-free asset which exists on most financial markets but not on human capital markets.
} 
deviation for a given mean or the highest mean for a given standard deviation. The exact point on the efficient frontier chosen by the agent depends on the shape of the investor's indifference curves.

Defining utility to depend directly on the mean and variance of the return on the human capital assets is a great advantage for empirical work, since they are observable (to the econometrician). Furthermore, investors do not value holding assets per se, but rather they value the stream of random cash flows that those assets give rise to. Therefore it is intuitively appealing that investors want higher mean and lower variance of expected returns ceteris paribus. However, many economists may be unhappy about a utility function that depends on income rather than consumption. Therefore, in the intertemporal consumption based asset pricing models utility depends on consumption. Investors pick consumption and assets to maximize their expected lifetime discounted utility. Hence, each time period investors decide how much to save, how much to consume, and which assets to include in their wealth portfolio. From the first order condition for this decision, we get the basic asset pricing equation:

$$
\begin{aligned}
& E_{t}\left\lfloor m_{t+1} R_{j, t+1}\right\rfloor=1, \\
& m_{t+1}=\beta \frac{u^{\prime}\left(c_{t+1}\right)}{u^{\prime}\left(c_{t}\right)},
\end{aligned}
$$

where $R_{j, t+1}$ is the return on asset $j$ at time $t+1, m_{t+1}$ is the intertemporal marginal rate of substitution (IMRS) between time $t$ and $t+1$ (also denoted the stochastic discount factor or the pricing kernel), and $E_{t}[\cdot]$ denotes the expectation conditional on the information available at time $t . \beta>0$ is the rate of time preference, $u(\cdot)$ is the utility function, and $c_{t}$ is consumption at time $t$. The basic pricing equation (2) should hold for any asset (stocks, bonds, options, real investments, etc.), and any monotone and concave utility function, $u(\cdot)$ with $u^{\prime}(\cdot)>0$ and $u^{\prime \prime}(\cdot)<0$. In particular, it holds for all human capital assets. Note that all asset specific risk corrections are driven by the covariance of the assets' return with the stochastic discount factor. Hence, riskier human capital assets must offer higher expected returns ceteris paribus to induce investors to hold them.

In spite of their theoretical appeal, the consumption based asset pricing models have not been found to perform well empirically; see discussion in Cochrane (2001; chapter 2). This is probably one of the reasons why meanvariance based models (including the CAPM) are still very popular in empirical applications, and most of the theory of asset pricing concerns how 
to proxy the stochastic discount factor in (3) with observable variables. ${ }^{3}$ Cochrane (2001; chapter 6) shows that various asset pricing model formulations are equivalent. We use Cochrane's equivalence result to relate the mean-variance model to the consumption based model in order to guarantee the existence of a stochastic discount factor, and to make transparent which assumptions we impose (and do not impose) in the empirical analysis. More heron follows in Section 2.3.

Performance measures rank assets by punishing the undertaken risk and assigning positive value to higher expected returns. The Sharpe (1965) ratio standardizes the excess return above the risk-free return by the standard deviation. The larger the Sharpe ratio is, the better the performance is. We apply a modified version of the Sharpe ratio, which we denote standardized returns, more heron follows in Section 2.5.

Hansen and Jagannathan (1991) provide a useful insight into the duality between discount factor volatility and Sharpe ratios. Since the basic pricing equation (2) holds for any asset, it can be written in terms of excess returns: $E_{t}\left\lfloor m_{t+1} R_{t+1}^{e}\right\rfloor=0$, where $R_{t+1}^{e}$ is the difference between any two asset returns. Hence, it implies that:

$$
\frac{\sigma\left(m_{t+1}\right)}{E\left[m_{t+1}\right]} \geq \frac{\mid E\left[R_{t+1}^{e}\right]}{\sigma\left(R_{t+1}^{e}\right)},
$$

which puts restrictions on the set of discount factors that can price a given set of asset returns. From equation (4) we see that the larger the maximum attainable Sharpe ratio (given by the right hand side), the tighter the bound on the volatility of the discount factor. The stochastic discount factors with the lowest volatility are the ones that correspond to mean-variance optimizing behavior. Hence, finding the mean-variance efficient assets is equivalent to finding the stochastic discount factor that has the lowest volatility among all the stochastic discount factors that price the given set of asset returns correctly.

We further examine the risk properties of the various human capital returns, by analyzing the mean-variance frontier spanned by different sets of assets. Thus, we also take the covariances between asset returns into account. Let $K$ denote the number of benchmark assets, and suppose that $J$ assets are added to the set of benchmark assets. We are interested in comparing the mean-

\footnotetext{
${ }^{3}$ For example, the CAPM ties the stochastic discount factor to the return on the wealth portfolio, $m_{t+1}=a+b R_{t+1}^{W}$, hence restricting it be a linear function of observed data.
} 
variance frontiers spanned by the $K$ benchmark assets and the larger set of $J+K$ assets, respectively. ${ }^{4}$ Mean-variance spanning occurs if the two efficient frontiers coincide, i.e. investors cannot benefit from the additional investment opportunities. In terms of volatility bounds, mean-variance spanning means that the stochastic discount factor with the lowest volatility that prices the $K$ benchmark asset returns correctly, is also the stochastic discount factor with the lowest volatility for the larger set of $J+K$ asset returns. We test the hypothesis of mean-variance spanning with the Wald test that is presented by de Roon and Nijman (2001), and it builds on the regression framework proposed by Huberman and Kandel (1987). ${ }^{5}$

We also estimate the increase in expected return per unit of risk that is obtained by adding more assets to the set of benchmark assets. More precisely, we estimate how much the mean-variance frontier changes at the expected value of the minimum volatility stochastic discount factor, which is typically close to one, $E\left[m_{t+1}\right] \approx 1$. From equation (4) we see that at this implied risk-free rate, ${ }_{R_{t+1}^{f}}^{f}=\frac{1}{E\left[m_{t+1}\right]} \approx 1$, the change in the expected return per unit of risk, $\Delta \sigma\left(m_{t+1}\right)$, is approximately equal to the change in the maximum attainable Sharpe ratio. A test of mean-variance spanning is equivalent to testing whether this change is zero. We estimate the potential improvement in the maximum attainable Sharpe ratio by the method described in de Roon and Nijman (2001). Since we are interested in comparing the properties of the different human capital returns, we estimate the increase in expected return per unit of risk when adding asset $j$ to asset $k$, and when adding asset $k$ to asset $j$, respectively. The net gain (or loss) from investing in asset $k$ rather than asset $j$ is then computed by subtracting the expected gain per unit of risk when $j$ is added to $k$ from the expected gain per unit of risk when $k$ is added to $j$.

Palacios-Huerta (2003a) uses a methodology similar to ours to incorporate riskiness into the comparison of human capital returns. He divides his data

\footnotetext{
${ }^{4}$ In the empirical analysis we investigate the special cases where $J=1$ and $K=1$ (Table 5), and $J=1$ and $K>1$ (Table 6).

${ }^{5}$ de Roon and Nijman (2001) provide a comprehensive survey of mean-variance spanning tests, and Bekaert and Urias (1996) examine the small sample properties of various meanvariance spanning tests. They find that the regression based test of Huberman and Kandel (1987) has higher power than the Generalized Method of Moments (GMM) based tests also commonly applied. Furthermore, Palacios-Huerta (2003a) finds that the two types of tests lead to almost identical conclusions.
} 
set into four demographic groups based on race (black/white) and sex, and then he divides the demographic groups into subgroups based on potential years of work experience and level of education. Each combination of experience and level of education is denoted a human capital asset. Palacios-Huerta (2003a) notes that human capital assets tend to have higher returns and lower variances than financial assets, i.e. they have higher Sharpe ratios. The Sharpe ratios increase with the level of education for a given demographic group. Palacios-Huerta (2003a) uses mean-variance spanning tests to compare the properties of the human capital returns by comparing the mean-variance frontiers spanned by different sets of assets. He shows that the efficient frontiers differ across demographic groups with identical level of education and experience. The efficient frontiers are composed of the relevant human capital assets for the group under investigation.

It is important to note that unlike us, Palacios-Huerta (2003a) does not apply information on the exact type of education. Therefore, he is not able to make any guidance as to which educations are efficient investment goods. We analyze the mean-variance efficient frontier of human capital assets for individuals with identical level of education, experience, normal working hours, and (academic) abilities, but different subject of education. Our results are much more detailed because we distinguish between as many as 104 human capital assets.

\subsection{Assumptions Imposed in Our Analysis}

There are two major differences between the market for human capital assets and the equity market. Firstly, diversification is not possible. However, small educational portfolios can be obtained by holding an interdisciplinary education. Moreover, another kind of portfolio is obtainable if couples or extended families choose their educations jointly, i.e. optimizing simultaneously. Yet, most people do not get married before undertaking an education and hardly any people live in extended families in the developed world. In the literature on the economics of marriage, a standard assumption is that the education, the earnings prospect of a potential partner, and the potential gains from household specialization are primary motivations for marriage formation; see for example Becker (1991). ${ }^{6}$ Therefore, marriage could be considered an educational portfolio

\footnotetext{
${ }^{6}$ Traditionally, the relevant specialization is into market work (males) and homework (females). However, in modern families of today the relevant issue is specialization in different sorts of market work.
} 
choice. In the present study we disregard portfolios of educations. Secondly, gearing is not possible. By gearing we mean that the investment cannot be scaled arbitrarily which is the way that arbitrage opportunities are done away with in financial markets. Finally, unlike equity investments, investing in a specific education is a binary choice variable: either you invest in a certain education or you do not. And this investment in education is irreversible: once you hold a certain education you are not able to sell it again.

Relating the mean-variance model to the consumption based model using the equivalence results of Cochrane (2001; chapter 6), we make transparent which assumptions that we make (and do not make) in our empirical application. First of all, we assume that the law of one price holds. Two perfectly correlated returns with different means are a violation of the law of one price; hence it implies that a mean-variance frontier exists (as well as a stochastic discount factor). However, markets are allowed to be incomplete in the sense that we do not assume absence of arbitrage. ${ }^{7}$ Since human capital assets cannot be sold and are extremely difficult to diversify, arbitrage opportunities on human capital markets are almost impossible to exploit in the short run. By only applying the law of one price and the basic pricing equation (2), we assume that risk is the only market friction. ${ }^{8}$ The existence and equivalence theorems proved by Cochrane (2001; chapter 6) hold for any set of probabilities, i.e. they hold equally well ex ante and ex post. However, by applying the basic pricing equation (2), we assume that investors can consider a small marginal investment or disinvestment. For investment in human capital assets, the investors cannot make a small marginal investment. Hence, the average value of an education not already undertaken might be substantially different from its marginal counterpart, and we cannot unravel the investor's ex ante marginal willingness to pay for the investment unless we assume perfect foresight or static earnings processes. However, the marginal valuation still applies ex post, illustrating what the investor actually paid for the educational investment in market equilibrium without imposing further assumptions.

\footnotetext{
${ }^{7}$ Absence of arbitrage implies that a portfolio that gives a non-negative future payoff and has a zero price now, does not exist. Assuming absence of arbitrage is equivalent to restricting the stochastic discount factor to be positive.

${ }^{8}$ Luttmer (1996) extends the framework to also take other market frictions into account, and Palacios-Huerta (2003c) finds that both risk and other market frictions help explain the human capital premium. Allowing for other market frictions implies that the basic pricing equation (2) holds with inequality, $E_{t}\left[m_{t+1} R_{t+1}\right] \leq 1$.
} 


\subsection{Efficient Frontiers}

We consider mean-variance plots of human capital investments in order to find the efficient frontier. Due to the limitations listed above, the meanvariance plot is a scatter-plot where the empirical efficient frontier consists of points rather than a continuous envelope curve. The mean-variance plot tells us which educations are efficient in the sense of an investment asset. In other words, if agents act as rational mean-variance optimizing investors, the plot has obvious implications for educational choices. Since public spending on education per year varies significantly across types of education, this may not be seen as a guide to policy makers about educational policy. Rather, it is a guide to individuals about what constitutes an efficient human capital investment from their point of view.

If agents tend to choose a certain education for other reasons than investment purposes, that asset would be situated in the interior of the feasible set. One reason could be that some people have a vocation for a certain education, e.g. nursing. ${ }^{9}$ This is the non-market benefit (or nonpecuniary returns, preferences, vocation or call) of education introduced by Heckman (1976). After controlling for the non-market benefit of education, Nielsen and Vissing-Jørgensen (2005) find that starting salary, income growth plus permanent and transitory income risk influence educational choice. Studying the choice between high school and college, Carneiro, Hansen and Heckman (2003) find that this non-market benefit is the main determinant of educational choice dominating pecuniary returns and risk. Looking at choices of college major, Arcidiacono (2004) finds that preferences for studying or working within the area related to a certain major explain educational choices. We assume that the non-pecuniary return is certain (i.e. we assume that it is uncorrelated with the stochastic discount factor). In principle, it could also be risky, since individuals do not know for sure whether they are going to like a certain education.

\subsection{Measures of Return and Risk}

We study individual time series of annual incomes within an educational group, which reflects the combined effect of employment, occupation, sector, and wage outcomes. Hence, the risk and return inherent in the annual income includes unemployment risk as well as low-income risk due to employment in unfavorable occupations or sectors.

\footnotetext{
${ }^{9}$ The stock market equivalent is investment in stocks of ones favorite football team etc.
} 
Unlike financial assets that yield the same return to all individuals, human capital asset returns vary across individuals depending on unobserved productivity related traits of the individual. The preferred return measure would be unaffected by ability differences across groups, as for instance reflected by average IQ, test scores, or family background for individuals within an educational group. ${ }^{10}$ However, test scores are only available for young high school graduates in our sample, whereas family background is only available for youth in the employed dataset. Therefore, we are not able to avoid ability bias in general. However, the problem is reduced when we refine the analysis to separately consider individuals who are expected to have similar unobserved abilities. This approach is applied for different subsamples in this study. We analyze individuals with academic abilities versus manual abilities, to be defined below. Furthermore, we briefly discuss individuals with revealed elitist academic ability.

As first discussed by Willis and Rosen (1979), returns to education may be affected by selection bias due to ability sorting. This effect is clearly confirmed by Carneiro et al. (2003) in the study of the choice of high school versus college. However, in studies of choice of college major, selection biases are found to be small after controlling for observed ability, see Berger (1988) and Arcidiacono (2004). These results indicate that individuals may not predict their position in the major-specific ability distribution better than the econometrician can based on observed ability variables. However, in our study we do not have access to observed ability variables. Instead we distinguish between manual and academic ability and discuss the choices of people with revealed elitist academic abilities. Furthermore, we investigate the four different fields of academic studies separately (humanities, social sciences, natural sciences and health care sciences) assuming that individuals who have chosen a given field of studies either have a comparative advantage or a general preference for that field such that their choice set effectively is restricted to that specific field.

When choosing a risk measure, it is important to separate risk from individual heterogeneity within an educational group. If individuals are informed about their draw of individual heterogeneity (e.g. IQ and motivation), this represents ex-ante risk, which is not compensated in the labor market. Therefore, we measure risk based on individual time series variances rather than cross sectional variance. ${ }^{11}$

\footnotetext{
${ }^{10}$ Consult Blackburn and Neumark (1995) and Card (1999) for a detailed discussion of ability bias.

${ }^{11}$ See Cunha, Heckman and Navarro (2005) who discuss the issue of separating risk from heterogeneity in detail.
} 
We use two different measures of returns to education:

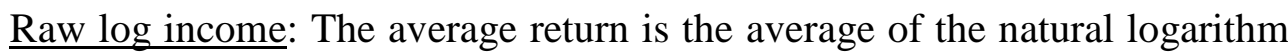
of annual income for workers within an educational group, $j$ :

$$
R_{j}=\frac{1}{n_{j}} \sum_{i=1}^{n_{j}} \frac{1}{n_{i}} \sum_{t=1}^{n_{i}} \ln W_{i j t}
$$

where $n_{j}$ denotes the number of workers in educational group $j$, and $n_{i}$ denotes the number of observations over time for worker $i$. Assuming independence, the corresponding standard deviation for educational group $j$ is the square root of the average variance of the annual income for workers within that educational group:

$$
\sigma_{j}=\sqrt{\frac{1}{n_{j}} \sum_{i=1}^{n_{j}} \sigma_{i j}^{2}},
$$

where $\sigma_{i j}^{2}$ is the time series variance of the annual income for worker $i$ in educational group $j$, given by:

$$
\sigma_{i j}^{2}=\frac{1}{n_{i}-1} \sum_{t=1}^{n_{i}}\left(\ln W_{i j t}-\overline{\ln W_{i j}}\right)^{2} .
$$

Mincer residuals: The Mincer residuals are applied to accommodate for differences in years of schooling across educations, differences in labor market experiences across individuals, and differences in normal working hours across educations.

The Mincer residuals are calculated as follows: First, the Mincer regression in equation (1) is estimated using all observations in the sample where we add the normal number of working hours for the educational group as an explanatory variable. Notice, we do not use individual observations of working hours. Second, the residuals are calculated as:

$$
\varepsilon_{i j t}=\ln W_{i j t}-\hat{\alpha}_{0}-\hat{\alpha}_{1} S_{i j t}-\hat{\alpha}_{2} X_{i j t}-\hat{\alpha}_{3} X_{i j t}{ }^{2}-\hat{\alpha}_{4} H_{j t},
$$

Third, the Mincer residuals are grouped according to education, and the means and the standard deviations are calculated for each group as before (with $\ln W_{i j t}$ replaced by $\varepsilon_{i j t}$ in equations (5) and (7)). Hence, the mean of Mincer residuals denotes the return to investing in a human capital asset relative to the average education of similar length with similar normal working hours corrected for differences in experience.

In Denmark, there are neither any Ivory League effects nor any tuition fees. All students are eligible for a Government grant that suffices for costs of 
living. As a consequence, time spent in the educational system is proportional to the amount invested in education in terms of foregone earnings from unskilled work. Hence, the return to education coefficient from a Mincer regression is a measure of the private return to education.

The parameter estimates for the Mincer regression are contained in Table 1. The return to schooling is around $1 \%$, i.e. $\widehat{\alpha}_{1}$ from equation (8). At first sight the return to schooling may seem small. Harmon, Walker, and Westergaard-Nielsen (2001) report rates of returns of $4-6 \%$ for the Scandinavian countries using gross hourly wages. For three reasons are our estimates smaller. First of all, since we use non-financial income after progressive taxation, the number should be smaller. Secondly, we use annual income rather than hourly income. Thirdly, taking account of the average number of working hours reduces the estimate for the return to schooling from around $3 \%$ to around $1 \%$.

For the Mincer residuals we compare human capital investment using a performance measure, namely, the standardized return. The standardized return for a human capital asset is simply calculated as the average Mincer residual for that human capital asset divided by its standard deviation.

\section{Empirical Analysis}

\subsection{Data}

We apply register-based panel data for a random sample of $10 \%$ of Danes. During the time period 1987-2000, we follow the cohorts born in 19471957. The dataset contains detailed information on educational attainments, actual labor market experience and several income variables at year-end. Each year the non-financial income after tax is recorded for each individual and converted to real amounts with 2000 as the base year. To make sure that outliers do not drive our results, we delete incomes below the $2^{\text {nd }}$ percentile and incomes above the $98^{\text {th }}$ percentile in the income distribution each year. We analyze time-series of individuals' non-financial after-tax income for each of 14 consecutive years to accommodate variations across business cycles.

The dataset is augmented with information from the Danish Labor Force Survey 2003 on normal weekly working hours. Hours are recorded separately for men and women in various educational groups.

Table 2 provides summary statistics for the pooled data set of real incomes. The average log income is DKK 12.01 with a standard deviation of DKK 0.43 . The average person in the sample is 42 years old, holds the equivalent 
of 12 years of completed education, has 16 years of work experience, and works for 35 hours during a normal week. ${ }^{12}$ The sample comprises $1,005,139$ observations of 80,722 individuals.

Detailed information on the highest level of education achieved is available. ${ }^{13}$ The sample is divided into educational groups of individuals with identical level and type of education providing us with 104 groups each consisting of at least 50 observations. The following educations receive special attention because they cover a wide spectrum of educations (years of schooling in parentheses): ${ }^{14}$ Appr. Shop Assistant (12), Appr. Bank Office Clerk (12), Appr. Electrician (12), Appr. Agriculture (12), Appr. Health Care (12), SCHE Armed forces (14), MCHE School Teacher (16), MCHE Nurse (16), MCHE Transport (16), MSc Economics (18), MSc Medicine (18), MSc Pharmacy (18), PhD Social Sciences (20), PhD Engineering (20), and $\mathrm{PhD}$ Medicine (20). ${ }^{15}$

The Appendix contains detailed information about the level and type of education for each of the 104 educational groups. The Appendix also contains the mean and the standard deviation (both for raw log income and for the Mincer residuals) for each educational group.

\subsection{Results: Raw Log Income}

Figure 2 shows the mean yearly income versus its standard deviation based on raw log income. The 15 educational groups singled out above are indicated with labels. The empirical efficient frontier consists of the points to the northwest. For instance, doing an MSc Economics is preferable to

\footnotetext{
${ }^{12}$ Starting in school at age seven, this implies seven years of idleness, which seems high at first sight. Deducting the wasted years in the educational system leaves less than five years for non-participation or unemployment, which makes sense for the relevant sample in the relevant observation period. On average one year is wasted in the educational system already to achieve the diploma of completion of basic school (late school start (0.3), grade repetition (0.1), an optional $10^{\text {th }}$ year in basic school (0.6)). On top of that comes drop out or lack of completion of higher education. For the cohorts in the sample, the completion rate was about $75 \%$ for short and medium cycle education, and less than $40 \%$ for long cycle higher education; see Ministry of Education (1998).

13 As the individuals in the sample are 30-53 years old, only very few $(<1 \%)$ are undertaking education during the sample period.

${ }^{14}$ Basic school, high school, and BA are excluded from the list to avoid the individuals who are dropouts from higher education.

${ }^{15}$ Appr. denotes Apprenticeship education, whereas SCHE and MCHE denotes short-cycle higher education and medium-cycle higher education, respectively.
} 
doing MCHE Nurse, because it gives a higher return while the standard deviation is the same. Likewise, doing SCHE Armed Forces is preferable to doing MSc Pharmacy, because it gives a lower standard deviation while the return is the same.

The efficient educations include MSc Medicine, MCHE Engineering, and SCHE Armed Forces. The efficient educations are comprised of long as well as short educations suggesting that years of schooling is not the only factor to consider when assessing the economic consequences of undertaking a given education.

There is a positive risk-return trade-off. Table 3 provides results from the WLS regression with weights reflecting the number of individuals in each group, in order to assign larger weight to groups with more individuals. The slope coefficient is significantly positive (66.8), indicating a positive riskreturn trade-off. ${ }^{16}$

\subsection{Results: Mincer Residuals}

Figure 3 illustrates the efficient frontier of the human capital market based on Mincer-residuals, thus correcting for the fact that the human capital assets represent different amounts of time invested, differences in experience, and varying working hours. The positive relationship between risk and return is not so clear from the graphical presentation. Still, the WLS regression reveals a significantly positive slope coefficient, 0.11 , cf. Table 3. So, even after correcting for differences in the length of education and years of experience, the positive risk-return relationship persists.

Focusing on the 15 educations from above, we find that the pattern is similar to that seen in Figure 2, though small changes do occur. For instance, MSc Economics moves up in the diagram. The efficient educations include MSc Medicine, MSc Economics, MCHE Engineering, and SCHE Armed Forces. Again we see that risk is not necessarily closely linked to the years of schooling.

In order to further assess the risk-return trade-off between the investment opportunities it is useful to apply the one-figure performance measure; the standardized return, introduced above. In Table 4 we have listed the standardized return for the groups with the five largest and the five smallest standardized returns as well as the ranking of the 15 groups of special

\footnotetext{
${ }^{16}$ We have investigated variation over gender, public/private sector, business cycles and employment rate. None of these factors are spuriously driving the results.
} 
attention. The top-performing educations include mainly long educations: MSc Medicine, MSc Dentistry, MCHE Engineering, MSc Economics and $\mathrm{PhD}$ Engineering. Still, long educations with poor performance exist, and short educations with good performance exist. Examples of poorly performing long educations are MCHE Needlework Teacher, MCHE Educator, and MA Education. Similarly, high-performing short educations include SCHE Armed forces, Appr. IT, High School, Appr. Electronics Mechanics, and Appr. Agriculture. The low-performance educations are dominated by apprenticeship and SCHE. Again, we conclude that when investing in human capital assets, the investor should find the type of education at least as interesting as the length of education. Note that the standardized returns range from -1.41 to 2.69 , i.e. they are in the same range as the Sharpe ratios for human capital assets in Palacios-Huerta (2003a), and higher than Sharpe ratios for financial assets (Sharpe ratios for stocks are typically around 0.5 ). This implies that the stochastic discount factors that price human capital assets are required to be more volatile than discount factors pricing financial assets.

\subsection{Results: Manual versus Academic Abilities}

It is unlikely that an individual chooses between Appr. Health Care and PhD Engineering. The reason is that the two educations attract individuals with different ability endowments. Below we study sub-sets of the feasible set. As an example, in Figure 4, we look at all apprenticeship educations separately and all MA/MSc educations separately, to resemble a situation where an individual has either manual or academic skills. Of course, any other set of educations reflecting the abilities or the choice set of the individual in question could be chosen. As mentioned earlier, empirical evidence shows that the bias due to selection on unobservables is significant for selection of level of education but not for selection of field of study (within a given level of education). Thus, the analysis here is presumably free of selection bias. ${ }^{17}$

The efficient educations among apprenticeship educations are Appr. Agriculture, Appr. IT, Appr. Electronics Mechanics, and Appr. Bank Office Clerk. The risk-return trade-off is negative for manual abilities; the

\footnotetext{
${ }^{17}$ If the results of Berger (1988) and Arcidiacono (2004) carry over to the case of Denmark, they suggest that the bias due to selection on unobservables is smaller when we consider a given level of education, even though we still cannot control for observed ability variables such as test scores or IQ. That is exactly what we do in the refined analysis where we compare manual and academic abilities, and single out elitist academic abilities.
} 
significant slope coefficient from WLS regression amounts to -0.75 , cf. Table 3.

For academic educations MSc Medicine, MSc Economics, MSc Pharmacy, MSc Armed Forces, and MSc ComputerScience/Math/Statistics are efficient educations. A long range of $\mathrm{MSc} / \mathrm{MA}$ educations are identified as consumption decisions, for example: Humanities, Theology, Letters, and Music/Aesthetics. The risk-return trade-off is positive as for the entire set of educations; the slope coefficient equals 1.43 which is significant.

Some of the academic educations require a high GPA to enter, e.g. Medicine, Dentistry, and Political Science. Therefore, individuals who complete these educations are revealed to have elitist academic abilities. We may therefore assume that those individuals would have been able to both enter and complete any other academic education. The human capital asset, MA Political Science, is an inefficient investment. Those investors could have achieved a $13 \%$ higher income at the same standard deviation, had they invested in the efficient asset, MSc Economics (see Table A1). Hence, people tend to choose MA Political Science for reasons other than investment purposes.

\subsection{Results: Mean-Variance Spanning Tests for Academic Educations}

At last we investigate the properties of the returns to academic educations in more detail relying on the Mincer residuals. For the academic educations, we perform a number of mean-variance spanning tests. Moreover, we estimate the increase in expected return per unit of risk when an education is added to a given benchmark education. These results are presented in Table 5. Complying with theory, the higher the p-value from the Wald test of mean-variance spanning is, the lower is the increase in expected return per unit of risk.

The hypothesis of mean-variance spanning is rejected in all cases when either the benchmark asset or the additional asset is one of the high performing educations: MSc Medicine and MSc Dentistry. This means that individuals can always gain by having one of these educations in their feasible set.

By studying the net gain from investing in one human capital asset rather than another, we see some non-trivial differences in these net gains. Corresponding to Figure $4 \mathrm{~b}$, we see that individuals with an MSc Economics education cannot gain from investing in MSc Engineering or MSc Pharmacy. With MSc Economics as the benchmark asset, the hypothesis of mean-variance spanning cannot be rejected when MSc 
Engineering or MSc Pharmacy are added to the feasible set. On the other hand, with either MSc Engineering or MSc Pharmacy as the benchmark asset, and MSc Economics is added to the feasible set, the mean-variance spanning hypothesis is clearly rejected. The expected net gain per unit of risk from choosing MSc Economics rather than MSc Engineering is 1.66, and from choosing MSc Economics rather than MSc Pharmacy it is 1.22.

There is a net gain from investing in a MA Business Language education relative to any other education. The net gain ranges from 0.96 (MA Theology) to 5.32 (MSc Computer Science, Mathematics, and Statistics). The biggest net losers are MA Education, MA Letters, and MSc Computer Science, Mathematics, and Statistics.

It is worth noting that only few individuals with academic abilities can be made better off by investing in a Natural Science education. For example, the hypothesis of mean-variance spanning is most often rejected when MSc Computer Science, Mathematics, and Statistics or MSc Geology and Geography are added to the benchmark human capital asset. On the other hand, the hypothesis of mean-variance spanning can never be rejected when one of these assets is the benchmark asset.

To reduce the potential role of ability bias even more, we compare the properties of human capital returns for individuals with academic abilities within a certain field of education. According to the Roy (1951) model, individuals self-select into the type of education where they have a comparative advantage, e.g. humanities, natural science, social science or health subjects. In Table 6, we consider mean-variance spanning tests for these four fields separately. Assume that individuals who have chosen an education within, for instance, the humanities have academic abilities within that specific field of education. Or alternatively, we could assume that these individuals have a general preference for educations within the humanities. For individuals who have a comparative advantage in the humanities, MA Business Language is an efficient investment. The gain per unit of risk from investing in MA Business Language rather than the optimal portfolio of the other educations within humanities is 4.13 . For individuals who have a comparative advantage in the natural sciences, MSc Engineering is an efficient investment. The gain per unit of risk from investing in MSc Engineering rather than the optimal portfolio of the other natural science educations amounts to 0.85. Likewise, for individuals who have a comparative advantage in the social sciences, MSc Economics would be an efficient investment. However, the gain per unit of risk from investing in MSc Economics rather than the optimal portfolio of the other social science educations is negligible. For individuals with a comparative advantage in health care sciences, there is some indication that all three feasible human 
capital assets: MSc Medicine, MSc Dentistry, and MSc Pharmacy, constitute efficient investments.

\section{Conclusion}

Earlier studies identify risk-return trade-offs and risk compensation by length of education. Using ideas from financial economics analysis of equity markets, we show a clear risk-return trade-off that is not only related to length of education but also to type of education.

We study mean-variance plots of human capital assets and compare the properties of human capital returns using a performance measure and tests for mean-variance spanning. The result of the empirical analysis is a classification of educations into efficient and inefficient investments among which the inefficient investments are supposedly chosen for reasons other than investment purposes (e.g. consumption purposes). All the empirical strategies lead to qualitatively similar conclusions.

Among the high-performing efficient educations we identify MSc in Medicine, MSc in Economics, MCHE Engineering and SCHE Armed Forces. Among inefficient educations that seem to be chosen for consumption purposes we find for instance educations related to Health and Education and MA educations related to the humanities. The picture is refined when we divide the educations into those requiring manual vs. academic abilities, and when we further divide the academic educations into fields of studies and when we look only at people with revealed elitist academic abilities. These divisions of the educations are done to better account for potential ability biases, and we identify MA Political Science as an education which is chosen for other purposes than investment purposes. 


\section{References}

Arcidiacono, P. (2004), "Ability Sorting and the Returns to College Major." Journal of Econometrics, 121(1-2): 343-375.

Beckaert, G. and M. S. Urias (1996), "Diversification, Integration, and Emerging Market Close-End Funds.” Journal of Finance 51(3): 835-870.

Becker, G. (1964, 1993), Human Capital: A Theoretical and Empirical Analysis with Special Reference to Education. Columbia UP: New York. First edition, 1964. Third edition, 1993.

Becker, G. (1991), A Treatise on the Family. Enlarged Edition. Harvard UP.

Becker, G. (1997), "Why a Crash Wouldn't Cripple the Economy." Business Week, April 14.

Berger, M. (1988), "Predicted Future Earnings and Choice of College Major." Industrial and Labor Relations Review 41(3): 418-429.

Blackburn, M. L. and D. Neumark (1995), "Are OLS Estimates of the Returns to Schooling Biased Downward? Another Look." Review of Economics and Statistics 77(2): 217-229.

Card, D. (1999), "The Causal Effect of Education on Earnings." Ch. 30 in Ashenfelter and Card, eds., Handbook of Labor Economics North-Holland.

Carneiro, P., K. T. Hansen and J. J. Heckman (2003), "Estimating Distributions of Treatment Effects with an Application to the Returns to Schooling and Measurement of the Effects of Uncertainty on College Choice." International Economic Review 44(2): 361-422.

Chen, S. H. (2003), "Does Wage Volatility Increase for College Attendees?" Manuscript, SUNY at Albany.

Christiansen, C, J. S. Joensen and J. Rangvid (2005), “Are Economists More Likely to Hold Stocks?" Manuscript, SSRN.

Cochrane, J. (2001), Asset Pricing, Princeton University Press.

Cunha, F., J. J. Heckman and S. Navarro (2005), "Separating Uncertainty from Heterogeneity in Life Cycle Earnings." Oxford Economic Papers 57(2): 191-261.

Fama, E. F. and G. W. Schwert (1977), "Human Capital and Capital Market Equilibrium." Journal of Financial Economics 4(1): 95-125. 
Fuchs-Schündeln, N. and M. Schündeln (2005), "Precautionary Savings and Self-selection: Evidence from the German Reunification 'Experiment'." Quarterly Journal of Economics 120(3): 1085-1120.

Haliassos, M. and C. C. Bertaut (1995), "Why Do So Few Hold Stocks?", Economic Journal 105, 1110-1129.

Hansen, L. P. and R. Jagannathan (1991), "Implication of Security Market Data for Models of Dynamic Economies." Journal of Political Economy 99 (2): $225-262$.

Harmon, C., V. Hogan and I. Walker (2003), "Dispersion in the Economic Return to Schooling." Labour Economics 10(2): 205-214.

Hartog J. and W. Vijverberg (2002), "Do Wages Really Compensate for Risk Aversion and Skewness Affection." IZA WP 426, Institute for Studies of Labor, Bonn, Germany.

Heckman, J. (1976), "A Life Cycle Model of Earnings, Learning, and Consumption." Journal of Political Economy 84 (1): 11-44.

Huberman, G. and S. Kandel (1987), "Mean-Variance Spanning." Journal of Finance 42(4): 873-888.

Hwang, H., W. R. Reed and C. Hubbard (1992), "Compensating Wage Differentials and Unobserved Productivity." Journal of Political Economy 100(4): 835-858.

Liberman, J. (1980), "Human Capital and the Financial Market." Journal of Business 53(2): 165-191.

Lintner, J. (1965), "The Valuation of Risk Assets and the Selection of Risky Investment in Stock Portfolios and Capital Budgets." Review of Economics and Statistics 47(1): 13-37.

Luttmer, E.G.J. (1996), "Asset pricing in Economies with Frictions." Econometrica 64(6): 1439-1467.

Markowitz, H. (1952), "Portfolio Selection.” Journal of Finance 7(1): 7799.

Mincer, J. A. (1974), Schooling, Experience, and Earnings. Columbia UP: New York.

Ministry of Education (1998), "Uddannelsessystemet i tal fra 1848 til 1998" Report (in Danish), the Ministry of Education, Denmark.

Nielsen, H. S. and A. Vissing-Jørgensen (2005), "The Impact of Labor Income Risk on Educational Choices: Estimates and Implied Risk Aversion." Manuscript, University of Aarhus, Denmark. 
Palacios-Huerta, I. (2003a), "An Empirical Analysis of the Risk Properties of Human Capital Returns.” American Economic Review 93: 948-964.

Palacios-Huerta, I. (2003b), "The Robustness of the Conditional CAPM with Human Capital." Journal of Financial Econometrics 1: 272-289.

Palacios-Huerta, I. (2003c), "Risk and Market Frictions as Determinants of the Human Capital Premium." Manuscript, Brown University.

Pereira, P. T. and P. S. Martins (2002), "Is there a Return-Risk Link in Education?" Economics Letters 75(1): 31-37.

Ribeiro, R. M. (2002), "Predictable Dividends and Returns." Manuscript, University of Chicago.

de Roon, F. A. and T. E. Nijman (2001), "Testing for Mean-Variance Spanning: A Survey." Journal of Empirical Finance 8(2): 111-155.

Rosen, S. (1986), “The Theory of Equalizing Differences" in Handbook of Labor Economics, vol.1, ed. O. Ashenfelter and R. Layard, 641-692, Amsterdam: North-Holland.

Roy, A. D. (1951), "Some Thoughts on the Distribution of Earnings." Oxford Economic Papers 3(2): 135-146.

Santos, T. and P. Veronesi (2001), "Labor Income and Predictable Stock Returns." Manuscript, University of Chicago.

Sharpe, W. F. (1964), "Capital Asset Prices: A Theory of Market Equilibrium under Conditions of Risk." Journal of Finance 19(3): 425-442.

Sharpe, W. F. (1965), "Mutual Fund Performance." Journal of Business 39(1): 119-138. 


\section{Appendix A. Educational groups}

Table A1: Descriptive statistics.

\begin{tabular}{|c|c|c|c|c|c|c|c|}
\hline \multirow[b]{2}{*}{ Explanation } & \multicolumn{2}{|c|}{ Raw Log Income } & \multicolumn{2}{|c|}{ Mincer Residuals } & \multirow[b]{2}{*}{ N_obs } & \multirow[b]{2}{*}{ N_pers } & \multirow[b]{2}{*}{$\begin{array}{l}\text { Length of } \\
\text { education }\end{array}$} \\
\hline & Mean & Std.Dev. & Mean & Std.Dev. & & & \\
\hline Basic School, 7 years & 11.80 & 0.18 & 0.03 & 0.18 & 175032 & 11882 & $\overline{7}$ \\
\hline Basic School. 9 years & 11.86 & 0.18 & 0.05 & 0.17 & 155112 & 11785 & 9 \\
\hline Preparatory School & 11.90 & 0.17 & 0.08 & 0.17 & 31797 & 2572 & 10 \\
\hline High School & 12.00 & 0.21 & 0.16 & 0.20 & 39606 & 3236 & 12 \\
\hline Appr. Education & 11.72 & 0.15 & -0.23 & 0.16 & 1028 & 69 & 12 \\
\hline Appr. General Business & 11.64 & 0.24 & -0.21 & 0.24 & 2842 & 249 & 12 \\
\hline Appr. Shop Assistant & 11.96 & 0.17 & -0.14 & 0.17 & 61815 & 4075 & 12 \\
\hline Appr. Wholesale Shop Assistant & 12.19 & 0.14 & -0.01 & 0.15 & 5212 & 439 & 12 \\
\hline Appr. Office Clerk & 11.98 & 0.16 & -0.12 & 0.16 & 77270 & 5085 & 12 \\
\hline Appr. Bank Office Clerk & 12.15 & 0.14 & -0.01 & 0.14 & 26061 & 1728 & 12 \\
\hline Appr. IT Office Clerk & 12.26 & 0.18 & 0.15 & 0.18 & 3025 & 229 & 12 \\
\hline Appr. Builder & 12.11 & 0.18 & -0.02 & 0.19 & 9504 & 620 & 12 \\
\hline Appr. Pavor & 12.11 & 0.15 & -0.04 & 0.16 & 343 & 26 & 12 \\
\hline Appr. Carpenter & 12.17 & 0.16 & 0.02 & 0.18 & 17915 & 1237 & 12 \\
\hline Appr. Joiner & 12.12 & 0.16 & -0.05 & 0.16 & 9875 & 645 & 12 \\
\hline Appr. Plumbing & 12.16 & 0.15 & 0.00 & 0.17 & 6114 & 418 & 12 \\
\hline Appr. Painter & 12.03 & 0.17 & -0.09 & 0.17 & 9220 & 611 & 12 \\
\hline Appr. Electrician & 12.21 & 0.14 & 0.03 & 0.15 & 13785 & 971 & 12 \\
\hline Appr. Construction & 11.89 & 0.21 & -0.13 & 0.21 & 1918 & 152 & 12 \\
\hline Appr. Metal & 12.12 & 0.15 & -0.05 & 0.16 & 18017 & 1206 & 12 \\
\hline Appr. Jeweller & 12.01 & 0.23 & -0.06 & 0.22 & 754 & 47 & 12 \\
\hline Appr. Fitter & 12.15 & 0.15 & -0.03 & 0.16 & 19587 & 1292 & 12 \\
\hline Appr. Mechanics & 12.18 & 0.14 & 0.01 & 0.16 & 30625 & 2082 & 12 \\
\hline Appr. Electronics Mechanics & 12.30 & 0.14 & 0.11 & 0.15 & 5704 & 406 & 12 \\
\hline Appr. IT Mechanics & 12.23 & 0.14 & 0.06 & 0.15 & 1363 & 102 & 12 \\
\hline Appr. Misc. Iron. Metal & 11.88 & 0.21 & -0.15 & 0.21 & 1981 & 162 & 12 \\
\hline Appr. Graphic & 12.19 & 0.17 & 0.03 & 0.18 & 7694 & 531 & 12 \\
\hline Appr. Photography & 12.12 & 0.26 & 0.05 & 0.26 & 942 & 60 & 12 \\
\hline Appr. Misc. Technical & 11.88 & 0.19 & -0.15 & 0.18 & 17986 & 1263 & 12 \\
\hline Appr. Service & 11.79 & 0.21 & -0.16 & 0.20 & 13159 & 891 & 12 \\
\hline Appr. Dairyman. Butcher & 12.13 & 0.17 & -0.06 & 0.18 & 5712 & 369 & 12 \\
\hline Appr. Baker & 12.16 & 0.16 & -0.01 & 0.18 & 4019 & 278 & 12 \\
\hline Appr. Cook. Waiter & 12.08 & 0.20 & -0.03 & 0.21 & 5821 & 460 & 12 \\
\hline Appr. Food & 11.79 & 0.18 & -0.19 & 0.18 & 2877 & 240 & 12 \\
\hline Appr. Agriculture & 12.35 & 0.24 & 0.18 & 0.24 & 6821 & 594 & 12 \\
\hline Appr. Gardener & 12.04 & 0.17 & -0.19 & 0.18 & 3117 & 218 & 12 \\
\hline Appr. Forestry & 12.15 & 0.22 & -0.15 & 0.21 & 96 & 7 & 12 \\
\hline Appr. Fishing & 12.22 & 0.23 & 0.04 & 0.24 & 812 & 59 & 12 \\
\hline Appr. Misc. Agriculture. Fishing & 12.24 & 0.25 & 0.08 & 0.26 & 2250 & 213 & 12 \\
\hline Appr. Transport & 11.96 & 0.20 & -0.10 & 0.21 & 3011 & 240 & 12 \\
\hline Appr. Dental Assistant & 11.76 & 0.19 & -0.19 & 0.18 & 6902 & 434 & 12 \\
\hline Appr. Health Care & 11.81 & 0.16 & -0.15 & 0.16 & 39353 & 2719 & 12 \\
\hline Appr. Health Care Assistant & 11.84 & 0.17 & -0.11 & 0.16 & 7762 & 515 & 12 \\
\hline
\end{tabular}




\begin{tabular}{|c|c|c|c|c|c|c|c|}
\hline SCHE Education & 12.18 & 0.14 & 0.01 & 0.14 & 415 & 24 & 14 \\
\hline SCHE Business Language & 12.02 & 0.18 & -0.04 & 0.18 & 7346 & 514 & 14 \\
\hline SCHE Music. Aesthetics & 11.89 & 0.24 & -0.06 & 0.24 & 2642 & 193 & 14 \\
\hline SCHE Social Sciences & 12.05 & 0.19 & -0.07 & 0.19 & 1308 & 119 & 14 \\
\hline SCHE Laboratory Assistant & 11.92 & 0.17 & -0.16 & 0.16 & 4765 & 327 & 14 \\
\hline SCHE Graphic & 11.89 & 0.27 & -0.05 & 0.26 & 204 & 15 & 14 \\
\hline SCHE Misc. Technical & 12.24 & 0.17 & 0.08 & 0.18 & 13289 & 903 & 14 \\
\hline SCHE Food & 12.00 & 0.16 & -0.12 & 0.16 & 4006 & 291 & 14 \\
\hline SCHE Agriculture. Fishing & 12.23 & 0.25 & 0.00 & 0.26 & 1289 & 115 & 14 \\
\hline SCHE Transport & 11.98 & 0.29 & 0.02 & 0.29 & 89 & 7 & 14 \\
\hline SCHE Health Care & 11.89 & 0.16 & -0.13 & 0.15 & 8861 & 544 & 14 \\
\hline SCHE Police. Warder & 12.31 & 0.12 & 0.06 & 0.14 & 6821 & 460 & 14 \\
\hline SCHE Armed Forces & 12.40 & 0.11 & 0.17 & 0.12 & 717 & 54 & 14 \\
\hline MCHE Educator & 11.94 & 0.17 & -0.16 & 0.15 & 46017 & 3219 & 16 \\
\hline MCHE School Teacher & 12.15 & 0.14 & 0.01 & 0.13 & 47277 & 3085 & 16 \\
\hline MCHE Needlework Teacher & 11.67 & 0.26 & -0.27 & 0.25 & 971 & 71 & 16 \\
\hline MCHE Journalism & 12.30 & 0.18 & 0.14 & 0.17 & 2245 & 160 & 16 \\
\hline MCHE Business Language & 12.01 & 0.15 & -0.02 & 0.14 & 3657 & 243 & 16 \\
\hline MCHE Music. Aesthetics & 11.78 & 0.24 & -0.10 & 0.24 & 301 & 17 & 16 \\
\hline MCHE Social Worker & 12.01 & 0.19 & -0.09 & 0.18 & 7436 & 491 & 16 \\
\hline MCHE Social Sciences & 12.11 & 0.18 & 0.00 & 0.17 & 208 & 16 & 16 \\
\hline MCHE Engineering & 12.52 & 0.14 & 0.31 & 0.15 & 9151 & 670 & 16 \\
\hline MCHE Misc. Technical & 12.30 & 0.18 & 0.14 & 0.18 & 8599 & 581 & 16 \\
\hline MCHE Food & 11.94 & 0.23 & -0.11 & 0.21 & 836 & 63 & 16 \\
\hline MCHE Agriculture. Fishing & 11.99 & 0.20 & -0.12 & 0.19 & 451 & 41 & 16 \\
\hline MCHE Transport & 12.41 & 0.18 & 0.21 & 0.19 & 5555 & 376 & 16 \\
\hline MCHE Nurse & 12.03 & 0.17 & -0.08 & 0.16 & 25394 & 1801 & 16 \\
\hline MCHE Midwife. Radiologist & 12.08 & 0.15 & -0.03 & 0.15 & 834 & 62 & 16 \\
\hline MCHE Physiotherapist etc. & 11.96 & 0.20 & -0.05 & 0.19 & 4824 & 345 & 16 \\
\hline MCHE Misc. & 11.97 & 0.17 & -0.20 & 0.16 & 3728 & 310 & 16 \\
\hline BA Humanities & 11.72 & 0.29 & -0.15 & 0.28 & 676 & 54 & 16 \\
\hline BA Natural Sciences & 11.89 & 0.32 & -0.23 & 0.29 & 179 & 11 & 16 \\
\hline BA Social Sciences & 12.36 & 0.20 & 0.19 & 0.21 & 2452 & 213 & 16 \\
\hline MA Education & 11.94 & 0.18 & -0.08 & 0.18 & 591 & 49 & 18 \\
\hline MA Humanities & 11.89 & 0.28 & -0.01 & 0.26 & 1194 & 105 & 18 \\
\hline MA Theology & 12.08 & 0.20 & 0.07 & 0.19 & 1636 & 108 & 18 \\
\hline MA History. Archaeology & 12.26 & 0.16 & 0.20 & 0.16 & 2933 & 198 & 18 \\
\hline MA Letters & 12.03 & 0.23 & 0.07 & 0.21 & 1797 & 127 & 18 \\
\hline MA Business Language (LSP) & 12.19 & 0.19 & 0.17 & 0.18 & 7642 & 536 & 18 \\
\hline MA Music. Aesthetics & 12.02 & 0.22 & 0.08 & 0.21 & 1250 & 80 & 18 \\
\hline MSc CompSci. Math. Statistics & 12.32 & 0.13 & 0.12 & 0.13 & 116 & 8 & 18 \\
\hline MSc Physics. Astronomy. Chemistry & 12.23 & 0.20 & 0.11 & 0.20 & 2564 & 209 & 18 \\
\hline MSc Geology. Geography & 12.18 & 0.19 & 0.10 & 0.18 & 612 & 47 & 18 \\
\hline MSc Biology. Sports & 12.23 & 0.20 & 0.11 & 0.18 & 2328 & 160 & 18 \\
\hline MSc Economics & 12.50 & 0.16 & 0.31 & 0.15 & 1816 & 152 & 18 \\
\hline MA Law (LLM) & 12.41 & 0.21 & 0.25 & 0.20 & 4933 & 386 & 18 \\
\hline MA Political Sciences. Sociology & 12.34 & 0.18 & 0.18 & 0.16 & 2585 & 180 & 18 \\
\hline
\end{tabular}




$\begin{array}{llllllll}\text { MA Misc. Social Sciences } & 12.25 & 0.24 & 0.14 & 0.23 & 6941 & 549 & 18 \\ \text { MSc Engineering } & 12.41 & 0.17 & 0.25 & 0.17 & 4579 & 376 & 18 \\ \text { MA Architecture (MAA) } & 12.26 & 0.21 & 0.15 & 0.21 & 3889 & 276 & 18 \\ \text { MA Agriculture. Food } & 12.36 & 0.20 & 0.23 & 0.19 & 2489 & 198 & 18 \\ \text { MSc Medicine } & 12.59 & 0.20 & 0.50 & 0.19 & 7111 & 602 & 18 \\ \text { MSc Dentistry } & 12.47 & 0.20 & 0.43 & 0.20 & 2134 & 164 & 18 \\ \text { MSc Pharmacy } & 12.39 & 0.16 & 0.26 & 0.15 & 1022 & 80 & 18 \\ \text { MSc Armed Forces } & 12.38 & 0.13 & 0.15 & 0.14 & 983 & 68 & 18 \\ \text { PhD Humanities } & 12.24 & 0.19 & 0.25 & 0.18 & 604 & 42 & 20 \\ \text { PhD Social Sciences } & 12.33 & 0.23 & 0.19 & 0.21 & 252 & 22 & 20 \\ \text { PhD Agriculture } & 12.38 & 0.15 & 0.23 & 0.15 & 306 & 26 & 20 \\ \text { PhD Natural Sciences } & 12.37 & 0.18 & 0.19 & 0.16 & 826 & 60 & 20 \\ \text { PhD Engineering. Technology } & 12.50 & 0.16 & 0.28 & 0.16 & 788 & 66 & 20 \\ \text { PhD Medicine } & 12.34 & 0.19 & 0.24 & 0.18 & 464 & 36 & 20\end{array}$

Note: The amounts are in DKK. The average exchange rate for 2000 is 0.1237 USD/DKK. Appr. is short for Apprenticeship, SCHE denotes short-cycle higher education, MCHE denotes medium-cycle higher education. 
Figure 1: Stylized Efficient Frontier

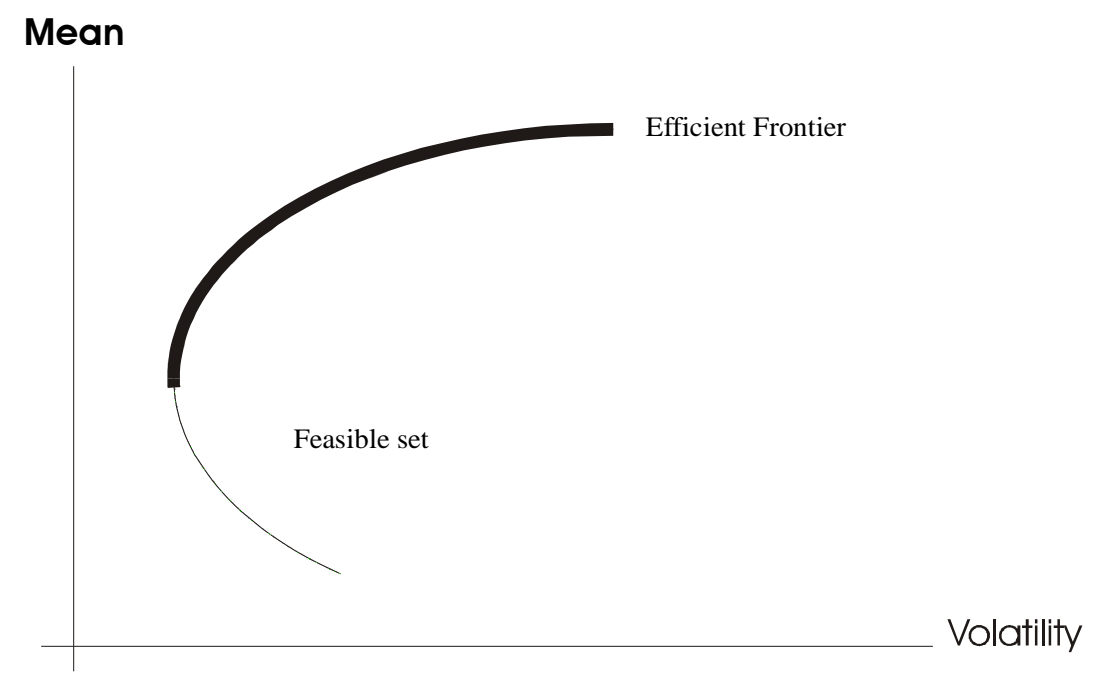


Figure 2: Efficient Frontier - Raw Log Income

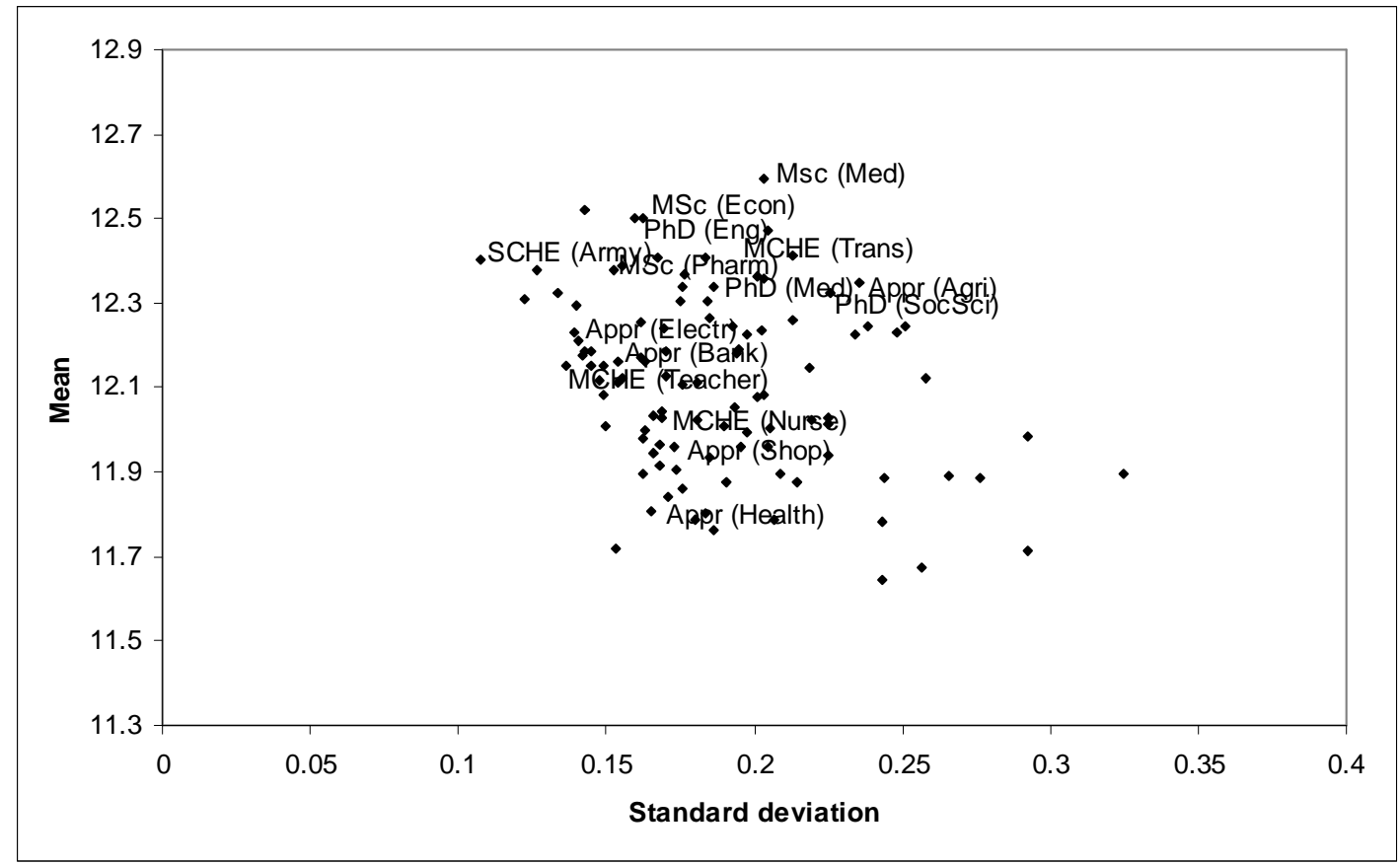


Figure 3: Efficient Frontier - Mincer Residuals

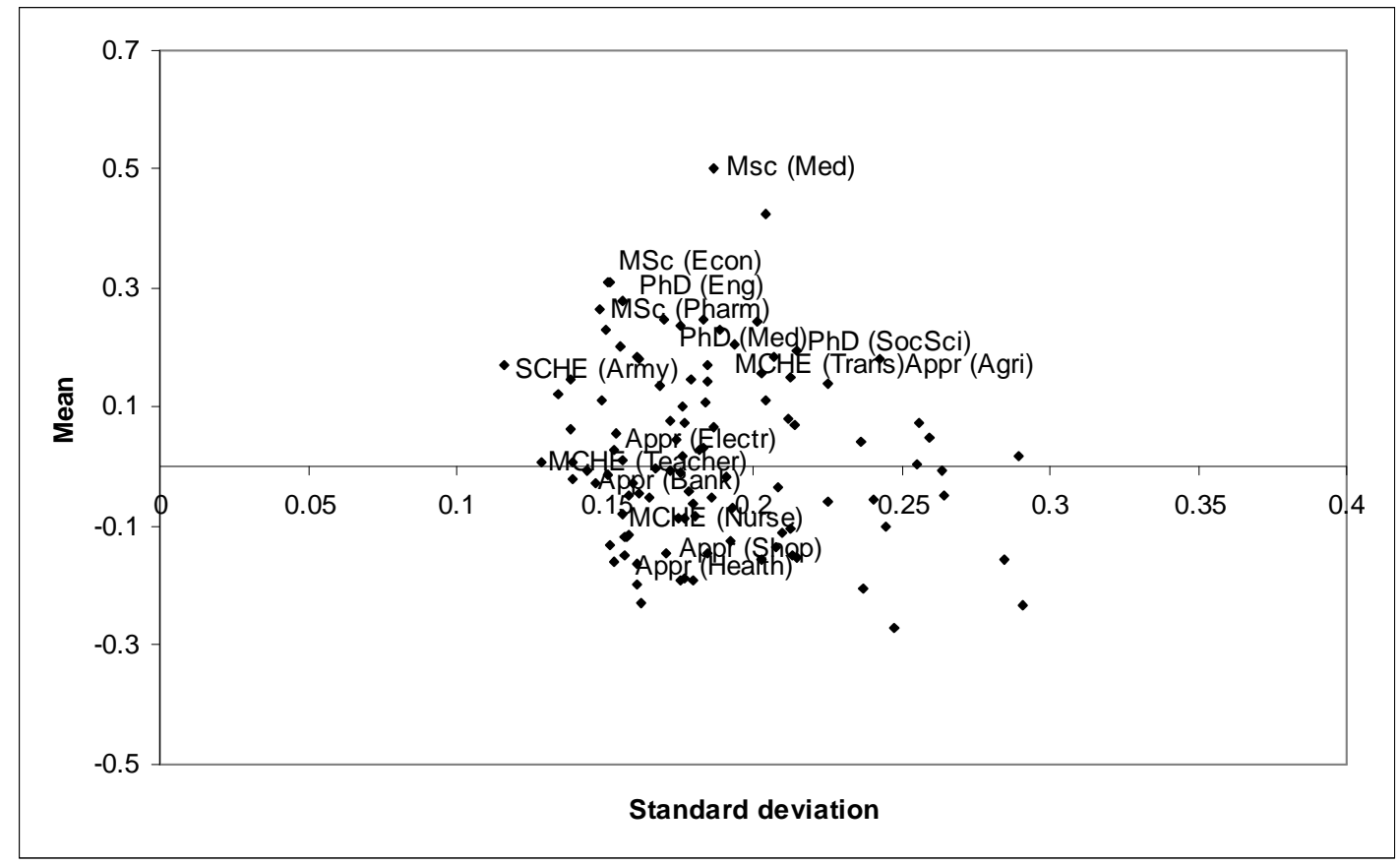


Figure 4: Manual/Academic Efficient Frontiers -Mincer Residuals

Figure 4a: Manual Abilities

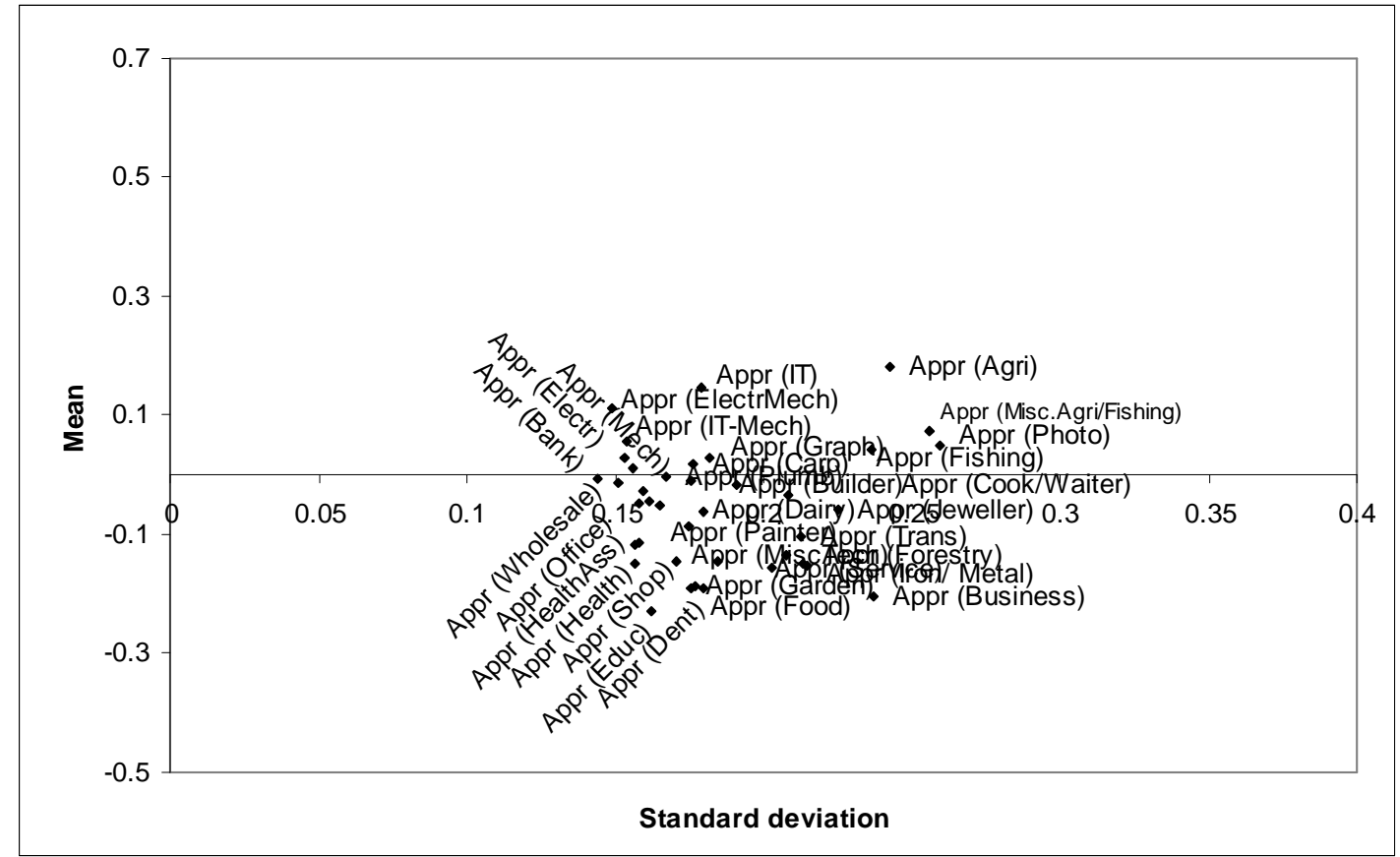

Figure 4b: Academic Abilities

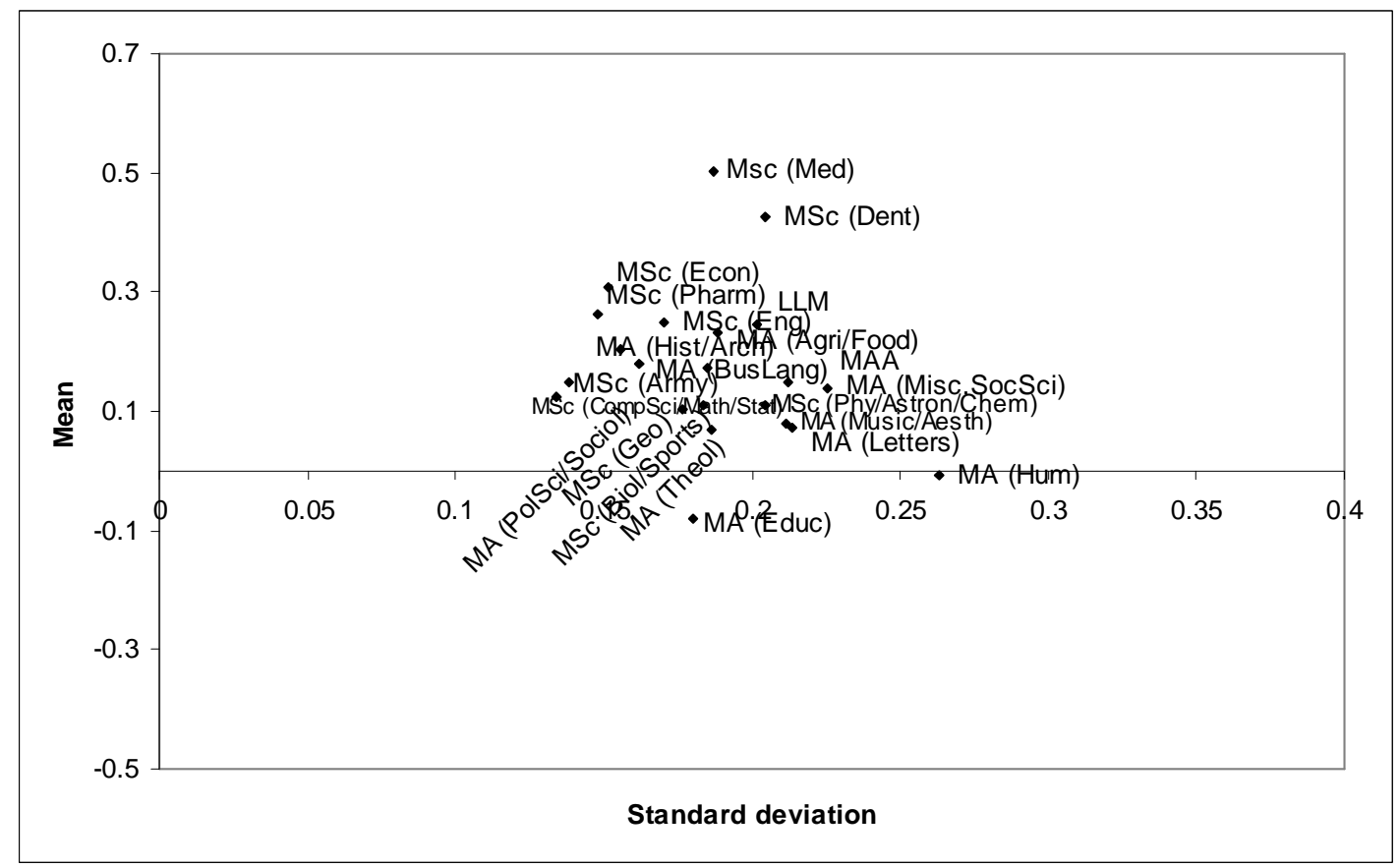


Table 1: Mincer Regression

The table shows the results of running the following regression: $\ln W_{i}=\alpha_{0}+\alpha_{1} S_{i}+\alpha_{2} X_{i}+\alpha_{3} X_{i}^{2}+\alpha_{4} H_{i}+\varepsilon_{i}$, where $\varepsilon_{i} \sim N\left(0, \sigma^{2}\right), X_{i}$ denotes years of experience, $S_{i}$ years of schooling, and $H_{i}$ normal number of working hours per week. Standard errors in parentheses. * indicates that the parameter is significant at $1 \%$ level of significance.

$\begin{array}{lrr}\text { Intercept }\left(\alpha_{0}\right) & 10.674 * & (0.0015) \\ \text { Years of schooling }\left(\alpha_{1}\right) & 0.011 * & (0.0002) \\ \text { Experience }\left(\alpha_{2}\right) & 0.034 * & (0.0002) \\ \text { Experience squared }\left(\alpha_{3}\right) & -0.001 * & (0.0000) \\ \text { Hours per week }\left(\alpha_{4}\right) & 0.024 * & (0.0001) \\ \boldsymbol{R}^{2} & 0.26 \\ \boldsymbol{N} & 1,005,139\end{array}$


Table 2: Descriptive statistics for pooled sample.

\begin{tabular}{lcc} 
& Mean & Std. Dev. \\
\hline Annual log income (DKK) & 12.01 & 0.43 \\
Age (years) & 41.54 & 5.26 \\
Accumulated education (years) & 11.86 & 3.09 \\
Experience (years) & 14.70 & 7.50 \\
Normal number of working hours per week & 35.13 & 0.39 \\
\hline Number of persons & \multicolumn{2}{c}{80,722} \\
Number of observations & \multicolumn{2}{c}{$1,005,139$}
\end{tabular}


Table 3: Weighted Least Squares Risk-Return Regressions.

The table shows the results of the WLS regressions of the equation: $\mu_{j}=\beta_{0}+\beta_{1} \sigma_{j}+\varepsilon_{j}$, where $\varepsilon_{j}$ are NIID error terms and weights are given by ${ }_{w_{j}}=\frac{n_{j}}{n} \cdot \mu_{j}$ denotes the mean and $\sigma_{j}$ denotes the standard deviation for educational group $j, j=1, \ldots K$. Standard errors in parenthesis. * indicates that the parameter is significant at $1 \%$ level of significance.

\begin{tabular}{lcccc} 
& $\boldsymbol{\beta}_{1}$ & $\boldsymbol{R}^{2}$ & $\boldsymbol{K}$ & $\boldsymbol{n}$ \\
\hline Raw Log Income & $66.81^{*}$ & 0.99 & 104 & $N$ \\
& $(0.53)$ & & & \\
Mincer Residuals & $0.11^{*}$ & 0.05 & 104 & $N$ \\
& $(0.05)$ & & & \\
Mincer Residuals - Manual Abilities & $-0.75^{*}$ & 0.75 & 39 & 34,684 \\
& $(0.07)$ & & & \\
Mincer Residuals - Academic Abilities & $1.43^{*}$ & 0.57 & 22 & 5,160
\end{tabular}


Table 4: Standardized Returns - Mincer Residuals

\begin{tabular}{ccl} 
Rank & $\begin{array}{c}\text { Standarized } \\
\text { Return }\end{array}$ & Education \\
\hline 1 & 2.69 & MSc Medicine \\
2 & 2.09 & MSc Dentistry \\
3 & 2.05 & MCHE Engineering \\
4 & 2.04 & MSc Economics \\
5 & 1.79 & PhD Engineering \\
\hline 6 & 1.79 & MSc Pharmacy \\
7 & 1.48 & SCHE Armed Forces \\
11 & 1.36 & PhD Medicine \\
18 & 1.06 & MCHE Transport \\
21 & 0.91 & PhD Social Sciences \\
28 & 0.75 & Appr. Agriculture \\
46 & 0.18 & Appr. Electrician \\
51 & 0.07 & MCHE School Teacher \\
57 & -0.04 & Appr. Bank Office Clerk \\
80 & -0.50 & MCHE Nurse \\
93 & -0.84 & Appr. Shop Assistant \\
96 & -0.95 & Appr. Health Care \\
\hline 100 & -1.07 & Appr. Food \\
101 & -1.08 & Appr. Dental Assistant \\
102 & -1.09 & MCHE Needlework Teacher \\
103 & -1.23 & MCHE Misc. \\
104 & -1.41 & Appr. Education
\end{tabular}


Table 5: Mean-Variance Spanning Tests and Increase in Expected Return per Unit of Risk.

The table shows the p-values of the Wald tests of the hypothesis of mean-variance spanning, $H_{0}: \alpha=0, \beta=1$, in the regressions of the additional asset returns, $R_{j, t+1}$, on the benchmark asset returns, $R_{k, t+1}$, i.e. $R_{j, t+1}=\alpha+\beta R_{k, t+1}+\varepsilon_{t+1}$, based on the Mincer residuals. The Wald test statistic is $F(2,12)$ distributed. Bold letters indicate that the hypothesis of mean-variance spanning cannot be rejected at a $1 \%$ level of significance. The estimated increase in expected return per unit of risk, $\Delta \sigma\left(m_{t+1}\right)$, is shown in parentheses.

\begin{tabular}{|c|c|c|c|c|c|c|c|c|c|c|c|}
\hline Additional assets & 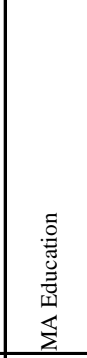 & 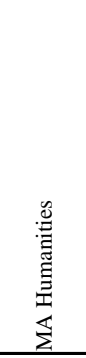 & 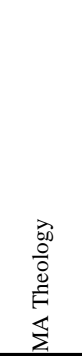 & 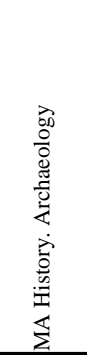 & 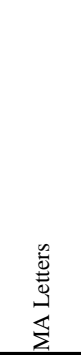 & 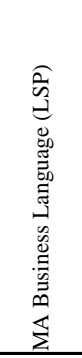 & 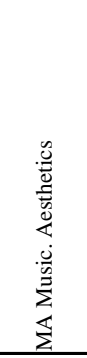 & 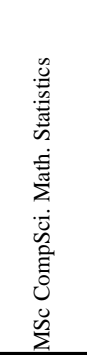 & 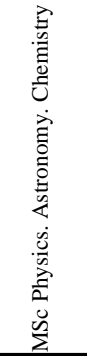 & 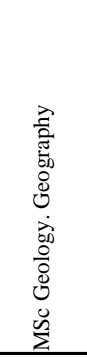 & 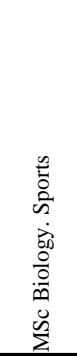 \\
\hline MA Education & - & $\begin{array}{c}\mathbf{0 . 1 0} \\
(3.51)\end{array}$ & $\begin{array}{c}0.01 \\
(3.56)\end{array}$ & $\begin{array}{c}0.00 \\
(0.88)\end{array}$ & $\begin{array}{c}0.00 \\
(3.97)\end{array}$ & $\begin{array}{c}0.00 \\
(2.07)\end{array}$ & $\begin{array}{c}0.01 \\
(2.11)\end{array}$ & $\begin{array}{c}0.00 \\
(2.25)\end{array}$ & $\begin{array}{c}0.00 \\
(1.81)\end{array}$ & $\begin{array}{c}0.00 \\
(3.15)\end{array}$ & $\begin{array}{c}0.00 \\
(0.96)\end{array}$ \\
\hline MA Humanities & $\begin{array}{c}0.00 \\
(4.70)\end{array}$ & - & $\begin{array}{c}0.00 \\
(5.03)\end{array}$ & $\begin{array}{c}0.00 \\
(3.95)\end{array}$ & $\begin{array}{c}0.00 \\
(2.85)\end{array}$ & $\begin{array}{c}0.00 \\
(2.74)\end{array}$ & $\begin{array}{c}0.00 \\
(1.87)\end{array}$ & $\begin{array}{c}0.00 \\
(3.51)\end{array}$ & $\begin{array}{c}0.00 \\
(4.95)\end{array}$ & $\begin{array}{c}0.00 \\
(3.45)\end{array}$ & $\begin{array}{c}0.00 \\
(2.97)\end{array}$ \\
\hline MA Theology & $\begin{array}{c}0.00 \\
(5.13)\end{array}$ & $\begin{array}{c}0.00 \\
(5.37)\end{array}$ & - & $\begin{array}{c}0.00 \\
(4.67)\end{array}$ & $\begin{array}{c}\mathbf{0 . 0 1} \\
(3.24)\end{array}$ & $\begin{array}{c}0.00 \\
(5.85)\end{array}$ & $\begin{array}{c}0.00 \\
(8.66)\end{array}$ & $\begin{array}{c}0.00 \\
(3.61)\end{array}$ & $\begin{array}{c}0.00 \\
(4.25)\end{array}$ & $\begin{array}{c}0.00 \\
(4.64)\end{array}$ & $\begin{array}{c}0.00 \\
(2.90)\end{array}$ \\
\hline MA History. Archaeology & $\begin{array}{c}0.00 \\
(3.62)\end{array}$ & $\begin{array}{c}0.00 \\
(4.72)\end{array}$ & $\begin{array}{c}0.00 \\
(5.12)\end{array}$ & - & $\begin{array}{c}0.00 \\
(4.87)\end{array}$ & $\begin{array}{c}\mathbf{0 . 5 9} \\
(1.63)\end{array}$ & $\begin{array}{c}0.00 \\
(1.70)\end{array}$ & $\begin{array}{c}0.00 \\
(2.83)\end{array}$ & $\begin{array}{c}0.00 \\
(2.34)\end{array}$ & $\begin{array}{c}0.00 \\
(3.29)\end{array}$ & $\begin{array}{c}0.00 \\
(2.76)\end{array}$ \\
\hline MA Letters & $\begin{array}{c}0.00 \\
(4.91)\end{array}$ & $\begin{array}{c}0.00 \\
(2.83)\end{array}$ & $\begin{array}{c}\mathbf{0 . 1 8} \\
(2.25)\end{array}$ & $\begin{array}{c}0.00 \\
(4.28)\end{array}$ & - & $\begin{array}{c}0.00 \\
(2.44)\end{array}$ & $\begin{array}{c}\mathbf{0 . 0 8} \\
(0.25)\end{array}$ & $\begin{array}{c}0.00 \\
(0.14)\end{array}$ & $\begin{array}{c}0.00 \\
(0.28)\end{array}$ & $\begin{array}{c}0.00 \\
(0.19)\end{array}$ & $\begin{array}{c}0.00 \\
(0.20)\end{array}$ \\
\hline MA Business Language (LSP) & $\begin{array}{c}0.00 \\
(6.88)\end{array}$ & $\begin{array}{c}0.00 \\
(6.38)\end{array}$ & $\begin{array}{c}0.00 \\
(6.81)\end{array}$ & $\begin{array}{c}0.00 \\
(4.97)\end{array}$ & $\begin{array}{c}0.00 \\
(6.03)\end{array}$ & - & $\begin{array}{c}0.00 \\
(5.09)\end{array}$ & $\begin{array}{c}0.00 \\
(5.55)\end{array}$ & $\begin{array}{c}0.00 \\
(5.64)\end{array}$ & $\begin{array}{c}0.00 \\
(5.87)\end{array}$ & $\begin{array}{c}0.00 \\
(6.28)\end{array}$ \\
\hline MA Music. Aesthetics & $\begin{array}{c}0.00 \\
(5.02)\end{array}$ & $\begin{array}{c}0.00 \\
(3.85)\end{array}$ & $\begin{array}{c}0.00 \\
(8.21)\end{array}$ & $\begin{array}{c}0.00 \\
(2.60)\end{array}$ & $\begin{array}{c}0.00 \\
(4.83)\end{array}$ & $\begin{array}{c}0.00 \\
(0.90)\end{array}$ & - & $\begin{array}{c}0.00 \\
(4.03)\end{array}$ & $\begin{array}{c}0.00 \\
(4.00)\end{array}$ & $\begin{array}{c}0.00 \\
(4.01)\end{array}$ & $\begin{array}{c}0.00 \\
(4.18)\end{array}$ \\
\hline MSc CompSci. Math. Statistics & $\begin{array}{c}\mathbf{0 . 0 1} \\
(0.93)\end{array}$ & $\begin{array}{c}\mathbf{0 . 0 2} \\
(2.41)\end{array}$ & $\begin{array}{c}\mathbf{0 . 3 8} \\
(1.39)\end{array}$ & $\begin{array}{c}\mathbf{0 . 2 1} \\
(0.46)\end{array}$ & $\begin{array}{c}\mathbf{0 . 0 8} \\
(3.80)\end{array}$ & $\begin{array}{c}\mathbf{0 . 4 3} \\
(0.24)\end{array}$ & $\begin{array}{c}\mathbf{0 . 5 2} \\
(1.40)\end{array}$ & - & $\begin{array}{c}\mathbf{0 . 8 5} \\
(0.28)\end{array}$ & $\begin{array}{c}0.00 \\
(3.23)\end{array}$ & $\begin{array}{c}\mathbf{0 . 8 5} \\
(0.19)\end{array}$ \\
\hline MSc Physics. Astronomy. Chemistry & $\begin{array}{c}0.00 \\
(2.11)\end{array}$ & $\begin{array}{c}0.00 \\
(5.22)\end{array}$ & $\begin{array}{c}\mathbf{0 . 0 3} \\
(3.44)\end{array}$ & $\begin{array}{c}0.01 \\
(0.04)\end{array}$ & $\begin{array}{c}0.00 \\
(6.98)\end{array}$ & $\begin{array}{c}\mathbf{0 . 0 6} \\
(1.28)\end{array}$ & $\begin{array}{c}\mathbf{0 . 2 0} \\
(1.32)\end{array}$ & $\begin{array}{c}0.00 \\
(1.62)\end{array}$ & - & $\begin{array}{c}0.00 \\
(2.58)\end{array}$ & $\begin{array}{c}\mathbf{0 . 3 9} \\
(0.95)\end{array}$ \\
\hline MSc Geology. Geography & $\begin{array}{c}\mathbf{0 . 0 2} \\
(3.16)\end{array}$ & $\begin{array}{c}\mathbf{0 . 0 5} \\
(1.20)\end{array}$ & $\begin{array}{c}\mathbf{0 . 0 8} \\
(4.94)\end{array}$ & $\begin{array}{c}\mathbf{0 . 0 6} \\
(0.74)\end{array}$ & $\begin{array}{c}\mathbf{0 . 0 9} \\
(3.91)\end{array}$ & $\begin{array}{c}\mathbf{0 . 1 0} \\
(0.57)\end{array}$ & $\begin{array}{c}\mathbf{0 . 5 9} \\
(2.19)\end{array}$ & $\begin{array}{c}0.00 \\
(2.97)\end{array}$ & $\begin{array}{c}\mathbf{0 . 1 6} \\
(1.87)\end{array}$ & - & $\begin{array}{c}\mathbf{0 . 6 2} \\
(1.02)\end{array}$ \\
\hline MSc Biology. Sports & $\begin{array}{c}0.00 \\
(2.86)\end{array}$ & $\begin{array}{c}0.00 \\
(2.91)\end{array}$ & $\begin{array}{c}\mathbf{0 . 0 8} \\
(1.69)\end{array}$ & $\begin{array}{c}0.00 \\
(1.78)\end{array}$ & $\begin{array}{c}0.00 \\
(4.79)\end{array}$ & $\begin{array}{c}0.00 \\
(4.72)\end{array}$ & $\begin{array}{c}\mathbf{0 . 1 0} \\
(3.06)\end{array}$ & $\begin{array}{c}0.00 \\
(2.52)\end{array}$ & $\begin{array}{c}0.01 \\
(2.32)\end{array}$ & $\begin{array}{c}0.00 \\
(2.99)\end{array}$ & - \\
\hline MSc Economics & $\begin{array}{c}0.00 \\
(3.45)\end{array}$ & $\begin{array}{c}0.00 \\
(3.36)\end{array}$ & $\begin{array}{c}0.00 \\
(4.94)\end{array}$ & $\begin{array}{c}0.00 \\
(0.42)\end{array}$ & $\begin{array}{c}0.00 \\
(5.10)\end{array}$ & $\begin{array}{c}0.00 \\
(3.74)\end{array}$ & $\begin{array}{c}0.00 \\
(1.57)\end{array}$ & $\begin{array}{c}0.00 \\
(2.68)\end{array}$ & $\begin{array}{c}0.00 \\
(2.31)\end{array}$ & $\begin{array}{c}0.00 \\
(3.07)\end{array}$ & $\begin{array}{c}0.00 \\
(2.18)\end{array}$ \\
\hline MA Law (LLM) & $\begin{array}{c}0.00 \\
(2.89)\end{array}$ & $\begin{array}{c}0.00 \\
(5.15)\end{array}$ & $\begin{array}{c}0.00 \\
(2.38)\end{array}$ & $\begin{array}{c}\mathbf{0 . 0 3} \\
(0.22)\end{array}$ & $\begin{array}{c}0.00 \\
(3.57)\end{array}$ & $\begin{array}{c}\mathbf{0 . 0 2} \\
(4.13)\end{array}$ & $\begin{array}{c}0.00 \\
(3.03)\end{array}$ & $\begin{array}{c}0.00 \\
(2.33)\end{array}$ & $\begin{array}{c}0.00 \\
(2.04)\end{array}$ & $\begin{array}{c}0.00 \\
(3.11)\end{array}$ & $\begin{array}{c}0.00 \\
(1.32)\end{array}$ \\
\hline MA Political Sciences. Sociology & $\begin{array}{c}0.00 \\
(3.97)\end{array}$ & $\begin{array}{c}0.00 \\
(3.09)\end{array}$ & $\begin{array}{c}0.00 \\
(5.74)\end{array}$ & $\begin{array}{c}\mathbf{0 . 1 9} \\
(0.62)\end{array}$ & $\begin{array}{c}0.00 \\
(5.52)\end{array}$ & $\begin{array}{c}\mathbf{0 . 8 5} \\
(0.41)\end{array}$ & $\begin{array}{c}0.00 \\
(1.88)\end{array}$ & $\begin{array}{c}0.00 \\
(2.80)\end{array}$ & $\begin{array}{c}0.00 \\
(2.43)\end{array}$ & $\begin{array}{c}0.00 \\
(3.16)\end{array}$ & $\begin{array}{c}0.00 \\
(2.40)\end{array}$ \\
\hline MA Misc. Social Sciences & $\begin{array}{c}0.00 \\
(4.98)\end{array}$ & $\begin{array}{c}0.00 \\
(4.49)\end{array}$ & $\begin{array}{c}0.00 \\
(4.93)\end{array}$ & $\begin{array}{c}0.00 \\
(1.94)\end{array}$ & $\begin{array}{c}0.00 \\
(6.14)\end{array}$ & $\begin{array}{c}0.01 \\
(0.87)\end{array}$ & $\begin{array}{c}0.00 \\
(2.29)\end{array}$ & $\begin{array}{c}0.00 \\
(3.83)\end{array}$ & $\begin{array}{c}0.00 \\
(3.51)\end{array}$ & $\begin{array}{c}0.00 \\
(4.01)\end{array}$ & $\begin{array}{c}0.00 \\
(3.01)\end{array}$ \\
\hline MSc Engineering & $\begin{array}{c}0.00 \\
(2.05)\end{array}$ & $\begin{array}{c}0.00 \\
(4.24)\end{array}$ & $\begin{array}{c}0.00 \\
(3.78)\end{array}$ & $\begin{array}{c}0.00 \\
(0.21)\end{array}$ & $\begin{array}{c}0.00 \\
(4.30)\end{array}$ & $\begin{array}{c}0.00 \\
(3.31)\end{array}$ & $\begin{array}{c}0.00 \\
(0.51)\end{array}$ & $\begin{array}{c}0.00 \\
(1.62)\end{array}$ & $\begin{array}{c}0.00 \\
(0.47)\end{array}$ & $\begin{array}{c}0.00 \\
(2.71)\end{array}$ & $\begin{array}{c}0.00 \\
(1.59)\end{array}$ \\
\hline MA Architecture (MAA) & $\begin{array}{c}0.00 \\
(2.71)\end{array}$ & $\begin{array}{c}0.00 \\
(3.70)\end{array}$ & $\begin{array}{c}\mathbf{0 . 0 2} \\
(3.52)\end{array}$ & $\begin{array}{c}\mathbf{0 . 0 1} \\
(0.02)\end{array}$ & $\begin{array}{c}0.00 \\
(7.40)\end{array}$ & $\begin{array}{c}\mathbf{0 . 0 7} \\
(2.61)\end{array}$ & $\begin{array}{c}\mathbf{0 . 1 2} \\
(1.92)\end{array}$ & $\begin{array}{c}0.00 \\
(1.87)\end{array}$ & $\begin{array}{c}\mathbf{0 . 3 3} \\
(0.70)\end{array}$ & $\begin{array}{c}0.00 \\
(2.19)\end{array}$ & $\begin{array}{c}\mathbf{0 . 4 0} \\
(0.50)\end{array}$ \\
\hline MA Agriculture. Food & $\begin{array}{c}0.00 \\
(3.22)\end{array}$ & $\begin{array}{c}0.00 \\
(3.13)\end{array}$ & $\begin{array}{c}0.00 \\
(5.49)\end{array}$ & $\begin{array}{c}0.00 \\
(1.48)\end{array}$ & $\begin{array}{c}0.00 \\
(6.23)\end{array}$ & $\begin{array}{c}0.00 \\
(1.92)\end{array}$ & $\begin{array}{c}0.00 \\
(2.51)\end{array}$ & $\begin{array}{c}0.00 \\
(2.67)\end{array}$ & $\begin{array}{c}0.00 \\
(2.29)\end{array}$ & $\begin{array}{c}0.00 \\
(3.26)\end{array}$ & $\begin{array}{c}0.00 \\
(2.04)\end{array}$ \\
\hline MSc Medicine & $\begin{array}{c}0.00 \\
(3.98)\end{array}$ & $\begin{array}{c}0.00 \\
(0.80)\end{array}$ & $\begin{array}{c}0.00 \\
(1.21)\end{array}$ & $\begin{array}{c}0.00 \\
(3.10)\end{array}$ & $\begin{array}{c}0.00 \\
(0.31)\end{array}$ & $\begin{array}{c}0.00 \\
(0.67)\end{array}$ & $\begin{array}{c}0.00 \\
(1.89)\end{array}$ & $\begin{array}{c}0.00 \\
(2.10)\end{array}$ & $\begin{array}{c}0.00 \\
(4.27)\end{array}$ & $\begin{array}{c}0.00 \\
(1.69)\end{array}$ & $\begin{array}{c}0.00 \\
(2.24)\end{array}$ \\
\hline MSc Dentistry & $\begin{array}{c}0.00 \\
(2.85)\end{array}$ & $\begin{array}{c}0.00 \\
(4.32)\end{array}$ & $\begin{array}{c}0.00 \\
(3.37)\end{array}$ & $\begin{array}{c}0.00 \\
(0.42)\end{array}$ & $\begin{array}{c}0.00 \\
(3.02)\end{array}$ & $\begin{array}{c}0.00 \\
(0.04)\end{array}$ & $\begin{array}{c}0.00 \\
(0.51)\end{array}$ & $\begin{array}{c}0.00 \\
(2.21)\end{array}$ & $\begin{array}{c}0.00 \\
(1.81)\end{array}$ & $\begin{array}{c}0.00 \\
(2.64)\end{array}$ & $\begin{array}{c}0.00 \\
(2.02)\end{array}$ \\
\hline MSc Pharmacy & $\begin{array}{c}0.00 \\
(2.47)\end{array}$ & $\begin{array}{c}0.00 \\
(4.18)\end{array}$ & $\begin{array}{c}0.00 \\
(3.50)\end{array}$ & $\begin{array}{c}0.00 \\
(0.07)\end{array}$ & $\begin{array}{c}0.00 \\
(4.24)\end{array}$ & $\begin{array}{c}0.00 \\
(0.27)\end{array}$ & $\begin{array}{c}0.00 \\
(1.21)\end{array}$ & $\begin{array}{c}0.00 \\
(1.86)\end{array}$ & $\begin{array}{c}0.00 \\
(1.10)\end{array}$ & $\begin{array}{c}0.00 \\
(2.41)\end{array}$ & $\begin{array}{c}0.00 \\
(1.31)\end{array}$ \\
\hline MSc Armed Forces & \begin{tabular}{|c}
0.00 \\
$(3.19)$
\end{tabular} & $\begin{array}{c}0.00 \\
(1.99)\end{array}$ & $\begin{array}{c}0.00 \\
(5.61)\end{array}$ & $\begin{array}{c}0.00 \\
(0.43)\end{array}$ & $\begin{array}{c}0.00 \\
(4.99)\end{array}$ & $\begin{array}{c}0.00 \\
(0.17)\end{array}$ & $\begin{array}{c}\mathbf{0 . 3 3} \\
(0.58)\end{array}$ & $\begin{array}{c}0.00 \\
(2.46)\end{array}$ & $\begin{array}{c}\mathbf{0 . 0 1} \\
(2.01)\end{array}$ & $\begin{array}{c}0.00 \\
(2.83)\end{array}$ & $\begin{array}{c}\mathbf{0 . 2 2} \\
(1.39)\end{array}$ \\
\hline
\end{tabular}


Table 5 (continued)

\begin{tabular}{|c|c|c|c|c|c|c|c|c|c|c|c|}
\hline 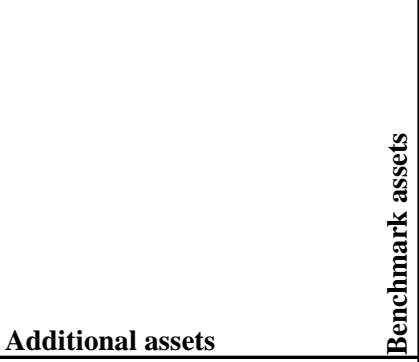 & 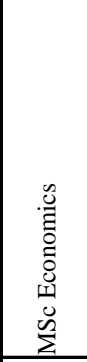 & 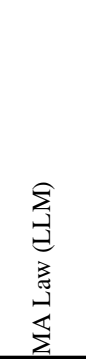 & 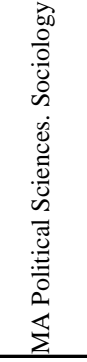 & 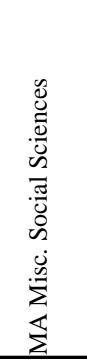 & 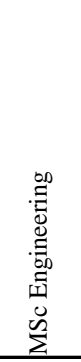 & 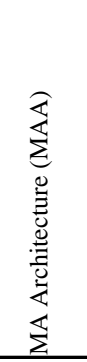 & 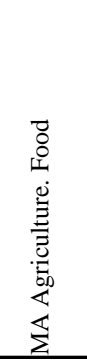 & 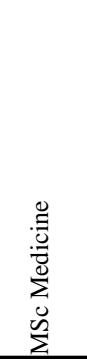 & 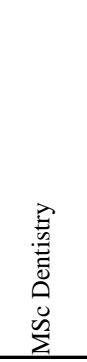 & 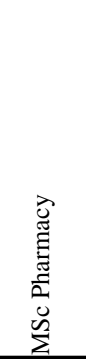 & 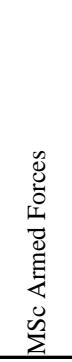 \\
\hline MA Education & $\begin{array}{c}0.00 \\
(0.55)\end{array}$ & $\begin{array}{c}0.00 \\
(1.07)\end{array}$ & $\begin{array}{c}0.00 \\
(1.81)\end{array}$ & $\begin{array}{c}0.00 \\
(1.87)\end{array}$ & $\begin{array}{c}0.00 \\
(1.13)\end{array}$ & $\begin{array}{c}0.00 \\
(2.05)\end{array}$ & $\begin{array}{c}0.00 \\
(0.46)\end{array}$ & $\begin{array}{c}0.00 \\
(2.78)\end{array}$ & $\begin{array}{c}0.00 \\
(0.44)\end{array}$ & $\begin{array}{c}0.00 \\
(0.98)\end{array}$ & $\begin{array}{c}0.00 \\
(1.26)\end{array}$ \\
\hline MA Humanities & $\begin{array}{c}0.00 \\
(2.14)\end{array}$ & $\begin{array}{c}0.00 \\
(4.63)\end{array}$ & $\begin{array}{c}0.00 \\
(2.36)\end{array}$ & $\begin{array}{c}0.00 \\
(2.95)\end{array}$ & $\begin{array}{c}0.00 \\
(3.82)\end{array}$ & $\begin{array}{c}0.00 \\
(3.90)\end{array}$ & $\begin{array}{c}0.00 \\
(2.38)\end{array}$ & $\begin{array}{c}0.00 \\
(1.39)\end{array}$ & $\begin{array}{c}0.00 \\
(3.76)\end{array}$ & $\begin{array}{c}0.00 \\
(3.58)\end{array}$ & $\begin{array}{c}0.00 \\
(1.96)\end{array}$ \\
\hline MA Theology & $\begin{array}{c}0.00 \\
(4.22)\end{array}$ & $\begin{array}{c}0.00 \\
(2.97)\end{array}$ & $\begin{array}{c}0.00 \\
(5.30)\end{array}$ & $\begin{array}{c}0.00 \\
(4.53)\end{array}$ & $\begin{array}{c}0.00 \\
(3.81)\end{array}$ & $\begin{array}{c}0.00 \\
(4.14)\end{array}$ & $\begin{array}{c}0.00 \\
(5.18)\end{array}$ & $\begin{array}{c}0.00 \\
(2.29)\end{array}$ & $\begin{array}{c}0.00 \\
(3.20)\end{array}$ & $\begin{array}{c}0.00 \\
(3.44)\end{array}$ & $\begin{array}{c}0.00 \\
(4.99)\end{array}$ \\
\hline MA History. Archaeology & $\begin{array}{c}0.00 \\
(0.26)\end{array}$ & $\begin{array}{c}0.00 \\
(1.31)\end{array}$ & $\begin{array}{c}\mathbf{0 . 1 0} \\
(0.90)\end{array}$ & $\begin{array}{c}0.00 \\
(0.13)\end{array}$ & $\begin{array}{c}0.00 \\
(1.54)\end{array}$ & $\begin{array}{c}0.00 \\
(2.22)\end{array}$ & $\begin{array}{c}0.00 \\
(1.68)\end{array}$ & $\begin{array}{c}0.00 \\
(3.03)\end{array}$ & $\begin{array}{c}0.00 \\
(0.67)\end{array}$ & $\begin{array}{c}0.00 \\
(1.10)\end{array}$ & $\begin{array}{c}0.00 \\
(1.47)\end{array}$ \\
\hline MA Letters & $\begin{array}{c}0.00 \\
(0.15)\end{array}$ & $\begin{array}{c}0.00 \\
(0.11)\end{array}$ & $\begin{array}{c}0.00 \\
(0.17)\end{array}$ & $\begin{array}{c}0.00 \\
(0.26)\end{array}$ & $\begin{array}{c}0.00 \\
(0.14)\end{array}$ & $\begin{array}{c}0.00 \\
(0.25)\end{array}$ & $\begin{array}{c}0.00 \\
(0.25)\end{array}$ & $\begin{array}{c}0.00 \\
(3.15)\end{array}$ & $\begin{array}{c}0.00 \\
(0.05)\end{array}$ & $\begin{array}{c}0.00 \\
(0.13)\end{array}$ & $\begin{array}{c}0.00 \\
(0.12)\end{array}$ \\
\hline MA Business Language (LSP) & $\begin{array}{c}0.00 \\
(4.96)\end{array}$ & $\begin{array}{c}0.00 \\
(5.67)\end{array}$ & $\begin{array}{c}0.00 \\
(4.91)\end{array}$ & $\begin{array}{c}0.00 \\
(4.79)\end{array}$ & $\begin{array}{c}0.00 \\
(4.86)\end{array}$ & $\begin{array}{c}0.00 \\
(5.85)\end{array}$ & $\begin{array}{c}0.00 \\
(5.12)\end{array}$ & $\begin{array}{c}0.00 \\
(4.24)\end{array}$ & $\begin{array}{c}0.00 \\
(4.09)\end{array}$ & $\begin{array}{c}0.00 \\
(4.54)\end{array}$ & $\begin{array}{c}0.00 \\
(4.98)\end{array}$ \\
\hline MA Music. Aesthetics & $\begin{array}{c}0.00 \\
(2.10)\end{array}$ & $\begin{array}{c}0.00 \\
(3.79)\end{array}$ & $\begin{array}{c}0.00 \\
(2.93)\end{array}$ & $\begin{array}{c}0.00 \\
(1.95)\end{array}$ & $\begin{array}{c}0.00 \\
(3.05)\end{array}$ & $\begin{array}{c}0.00 \\
(3.97)\end{array}$ & $\begin{array}{c}0.00 \\
(3.22)\end{array}$ & $\begin{array}{c}0.00 \\
(2.89)\end{array}$ & $\begin{array}{c}0.00 \\
(1.87)\end{array}$ & $\begin{array}{c}0.00 \\
(2.86)\end{array}$ & $\begin{array}{c}0.00 \\
(2.42)\end{array}$ \\
\hline MSc CompSci. Math. Statistics & $\begin{array}{c}0.00 \\
(0.94)\end{array}$ & $\begin{array}{c}\mathbf{0 . 0 7} \\
(0.01)\end{array}$ & $\begin{array}{c}\mathbf{0 . 4 6} \\
(0.06)\end{array}$ & $\begin{array}{c}\mathbf{0 . 2 9} \\
(3.38)\end{array}$ & $\begin{array}{c}0.00 \\
(0.04)\end{array}$ & $\begin{array}{c}\mathbf{0 . 9 8} \\
(0.03)\end{array}$ & $\begin{array}{c}\mathbf{0 . 0 1} \\
(1.29)\end{array}$ & $\begin{array}{c}0.00 \\
(1.79)\end{array}$ & $\begin{array}{c}0.00 \\
(0.13)\end{array}$ & $\begin{array}{c}0.00 \\
(0.05)\end{array}$ & $\begin{array}{c}\mathbf{0 . 7 1} \\
(0.32)\end{array}$ \\
\hline MSc Physics. Astronomy. Chemistry & $\begin{array}{c}0.00 \\
(0.00)\end{array}$ & $\begin{array}{c}0.00 \\
(0.63)\end{array}$ & $\begin{array}{c}\mathbf{0 . 0 7} \\
(0.15)\end{array}$ & $\begin{array}{c}\mathbf{0 . 2 2} \\
(1.69)\end{array}$ & $\begin{array}{c}0.00 \\
(0.10)\end{array}$ & $\begin{array}{c}\mathbf{0 . 5 9} \\
(0.37)\end{array}$ & $\begin{array}{c}0.00 \\
(0.02)\end{array}$ & $\begin{array}{c}0.00 \\
(3.84)\end{array}$ & $\begin{array}{c}0.00 \\
(0.01)\end{array}$ & $\begin{array}{c}0.00 \\
(0.11)\end{array}$ & $\begin{array}{c}\mathbf{0 . 4 2} \\
(0.31)\end{array}$ \\
\hline MSc Geology. Geography & $\begin{array}{c}0.00 \\
(0.33)\end{array}$ & $\begin{array}{c}0.01 \\
(1.93)\end{array}$ & $\begin{array}{c}\mathbf{0 . 1 1} \\
(0.53)\end{array}$ & $\begin{array}{c}\mathbf{0 . 3 2} \\
(0.25)\end{array}$ & $\begin{array}{c}0.00 \\
(1.88)\end{array}$ & $\begin{array}{c}\mathbf{0 . 4 2} \\
(0.69)\end{array}$ & $\begin{array}{c}0.01 \\
(1.28)\end{array}$ & $\begin{array}{c}0.00 \\
(0.77)\end{array}$ & $\begin{array}{c}0.00 \\
(0.55)\end{array}$ & $\begin{array}{c}0.00 \\
(0.73)\end{array}$ & $\begin{array}{c}\mathbf{0 . 8 1} \\
(0.35)\end{array}$ \\
\hline MSc Biology. Sports & $\begin{array}{c}0.00 \\
(0.84)\end{array}$ & $\begin{array}{c}0.00 \\
(1.20)\end{array}$ & $\begin{array}{c}0.00 \\
(1.56)\end{array}$ & $\begin{array}{c}\mathbf{0 . 0 5} \\
(0.05)\end{array}$ & $\begin{array}{c}0.00 \\
(2.03)\end{array}$ & $\begin{array}{c}\mathbf{0 . 0 2} \\
(1.82)\end{array}$ & $\begin{array}{c}0.00 \\
(1.08)\end{array}$ & $\begin{array}{c}0.00 \\
(2.22)\end{array}$ & $\begin{array}{c}0.00 \\
(1.27)\end{array}$ & $\begin{array}{c}0.00 \\
(1.41)\end{array}$ & $\begin{array}{c}\mathbf{0 . 1 8} \\
(1.17)\end{array}$ \\
\hline MSc Economics & - & $\begin{array}{c}0.00 \\
(1.65)\end{array}$ & $\begin{array}{c}0.00 \\
(0.73)\end{array}$ & $\begin{array}{c}0.00 \\
(0.34)\end{array}$ & $\begin{array}{c}0.00 \\
(1.78)\end{array}$ & $\begin{array}{c}0.00 \\
(1.93)\end{array}$ & $\begin{array}{c}0.00 \\
(0.80)\end{array}$ & $\begin{array}{c}0.00 \\
(2.44)\end{array}$ & $\begin{array}{c}0.00 \\
(1.18)\end{array}$ & $\begin{array}{c}\mathbf{0 . 0 1} \\
(1.25)\end{array}$ & $\begin{array}{c}0.00 \\
(1.25)\end{array}$ \\
\hline MA Law (LLM) & $\begin{array}{c}0.00 \\
(0.54)\end{array}$ & - & $\begin{array}{c}0.01 \\
(1.18)\end{array}$ & $\begin{array}{c}0.00 \\
(0.90)\end{array}$ & $\begin{array}{c}0.00 \\
(1.24)\end{array}$ & $\begin{array}{c}0.00 \\
(1.81)\end{array}$ & $\begin{array}{c}\mathbf{0 . 1 3} \\
(1.60)\end{array}$ & $\begin{array}{c}0.00 \\
(2.70)\end{array}$ & $\begin{array}{c}0.00 \\
(0.32)\end{array}$ & $\begin{array}{c}0.00 \\
(0.62)\end{array}$ & $\begin{array}{c}0.00 \\
(1.72)\end{array}$ \\
\hline MA Political Sciences. Sociology & $\begin{array}{c}0.00 \\
(0.29)\end{array}$ & $\begin{array}{c}0.00 \\
(1.85)\end{array}$ & - & $\begin{array}{c}\mathbf{0 . 0 8} \\
(0.19)\end{array}$ & $\begin{array}{c}0.00 \\
(1.68)\end{array}$ & $\begin{array}{c}0.00 \\
(2.05)\end{array}$ & $\begin{array}{c}0.00 \\
(0.77)\end{array}$ & $\begin{array}{c}0.00 \\
(2.38)\end{array}$ & $\begin{array}{c}0.00 \\
(1.75)\end{array}$ & $\begin{array}{c}0.00 \\
(1.30)\end{array}$ & $\begin{array}{c}0.00 \\
(1.06)\end{array}$ \\
\hline MA Misc. Social Sciences & $\begin{array}{c}0.00 \\
(1.62)\end{array}$ & $\begin{array}{c}0.00 \\
(2.95)\end{array}$ & $\begin{array}{c}0.00 \\
(2.24)\end{array}$ & - & $\begin{array}{c}0.00 \\
(2.77)\end{array}$ & $\begin{array}{c}0.00 \\
(3.31)\end{array}$ & $\begin{array}{c}0.00 \\
(2.50)\end{array}$ & $\begin{array}{c}0.00 \\
(3.14)\end{array}$ & $\begin{array}{c}0.00 \\
(1.80)\end{array}$ & $\begin{array}{c}0.00 \\
(2.33)\end{array}$ & $\begin{array}{c}0.00 \\
(2.44)\end{array}$ \\
\hline MSc Engineering & $\begin{array}{c}\mathbf{0 . 4 9} \\
(0.12)\end{array}$ & $\begin{array}{c}\mathbf{0 . 0 5} \\
(0.41)\end{array}$ & $\begin{array}{c}0.00 \\
(0.10)\end{array}$ & $\begin{array}{c}0.00 \\
(0.72)\end{array}$ & - & $\begin{array}{c}0.00 \\
(1.12)\end{array}$ & $\begin{array}{c}\mathbf{0 . 2 2} \\
(0.43)\end{array}$ & $\begin{array}{c}0.00 \\
(2.85)\end{array}$ & $\begin{array}{c}0.00 \\
(0.00)\end{array}$ & $\begin{array}{c}\mathbf{0 . 1 1} \\
(0.13)\end{array}$ & $\begin{array}{c}0.00 \\
(0.17)\end{array}$ \\
\hline MA Architecture (MAA) & $\begin{array}{c}0.00 \\
(0.25)\end{array}$ & $\begin{array}{c}0.00 \\
(0.65)\end{array}$ & $\begin{array}{c}\mathbf{0 . 0 5} \\
(0.01)\end{array}$ & $\begin{array}{c}\mathbf{0 . 3 8} \\
(1.03)\end{array}$ & $\begin{array}{c}0.00 \\
(0.86)\end{array}$ & - & $\begin{array}{c}0.00 \\
(0.13)\end{array}$ & $\begin{array}{c}0.00 \\
(2.69)\end{array}$ & $\begin{array}{c}0.00 \\
(0.74)\end{array}$ & $\begin{array}{c}0.00 \\
(0.20)\end{array}$ & $\begin{array}{c}\mathbf{0 . 2 8} \\
(0.46)\end{array}$ \\
\hline MA Agriculture. Food & $\begin{array}{c}0.00 \\
(0.43)\end{array}$ & $\begin{array}{c}\mathbf{0 . 0 1} \\
(2.17)\end{array}$ & $\begin{array}{c}0.00 \\
(0.86)\end{array}$ & $\begin{array}{c}0.00 \\
(0.96)\end{array}$ & $\begin{array}{c}0.00 \\
(1.85)\end{array}$ & $\begin{array}{c}0.00 \\
(1.88)\end{array}$ & - & $\begin{array}{c}0.00 \\
(2.61)\end{array}$ & $\begin{array}{c}0.00 \\
(1.96)\end{array}$ & $\begin{array}{c}0.00 \\
(1.26)\end{array}$ & $\begin{array}{c}0.00 \\
(1.35)\end{array}$ \\
\hline MSc Medicine & $\begin{array}{c}0.00 \\
(1.93)\end{array}$ & $\begin{array}{c}0.00 \\
(2.89)\end{array}$ & $\begin{array}{c}0.00 \\
(2.04)\end{array}$ & $\begin{array}{c}0.00 \\
(2.72)\end{array}$ & $\begin{array}{c}0.00 \\
(2.98)\end{array}$ & $\begin{array}{c}0.00 \\
(3.04)\end{array}$ & $\begin{array}{c}0.00 \\
(2.61)\end{array}$ & - & $\begin{array}{c}0.00 \\
(2.22)\end{array}$ & $\begin{array}{c}0.00 \\
(2.10)\end{array}$ & $\begin{array}{c}0.00 \\
(1.81)\end{array}$ \\
\hline MSc Dentistry & $\begin{array}{c}0.00 \\
(0.77)\end{array}$ & $\begin{array}{c}0.00 \\
(0.96)\end{array}$ & $\begin{array}{c}0.00 \\
(1.78)\end{array}$ & $\begin{array}{c}0.00 \\
(0.15)\end{array}$ & $\begin{array}{c}0.00 \\
(1.11)\end{array}$ & $\begin{array}{c}0.00 \\
(2.15)\end{array}$ & $\begin{array}{c}0.00 \\
(1.98)\end{array}$ & $\begin{array}{c}0.00 \\
(2.19)\end{array}$ & - & $\begin{array}{c}0.00 \\
(0.85)\end{array}$ & $\begin{array}{c}0.00 \\
(1.26)\end{array}$ \\
\hline MSc Pharmacy & $\begin{array}{c}\mathbf{0 . 6 8} \\
(0.03)\end{array}$ & $\begin{array}{c}0.00 \\
(0.23)\end{array}$ & $\begin{array}{c}0.00 \\
(0.22)\end{array}$ & $\begin{array}{c}0.00 \\
(0.84)\end{array}$ & $\begin{array}{c}\mathbf{0 . 0 2} \\
(0.56)\end{array}$ & $\begin{array}{c}0.00 \\
(0.93)\end{array}$ & $\begin{array}{c}0.00 \\
(0.18)\end{array}$ & $\begin{array}{c}0.00 \\
(2.19)\end{array}$ & $\begin{array}{c}0.00 \\
(0.07)\end{array}$ & - & $\begin{array}{c}0.00 \\
(0.56)\end{array}$ \\
\hline MSc Armed Forces & $\begin{array}{c}0.00 \\
(0.13)\end{array}$ & $\begin{array}{c}0.00 \\
(1.83)\end{array}$ & $\begin{array}{c}0.00 \\
(0.20)\end{array}$ & $\begin{array}{c}0.00 \\
(1.61)\end{array}$ & $\begin{array}{c}0.00 \\
(1.21)\end{array}$ & $\begin{array}{c}\mathbf{0 . 0 2} \\
(1.85)\end{array}$ & $\begin{array}{c}0.00 \\
(0.50)\end{array}$ & $\begin{array}{c}0.00 \\
(2.14)\end{array}$ & $\begin{array}{c}0.00 \\
(0.69)\end{array}$ & $\begin{array}{c}0.00 \\
(1.00)\end{array}$ & - \\
\hline
\end{tabular}


Table 6: Mean-Variance Spanning Tests and Increase in Expected Return per Unit of Risk.

The table shows the p-values of the Wald tests of the hypothesis of mean-variance spanning, $H_{0}: \alpha=0, \sum_{k=1}^{K} \beta_{k}=1$, in the regressions of the additional asset returns, $R_{j, t+1}$, on the $K$ benchmark asset returns, $R_{k, t+1}$, i.e. $R_{j, t+1}=\alpha+\beta_{1} R_{1, t+1}+\ldots+\beta_{K} R_{K, t+1}+\varepsilon_{t+1}$, based on the Mincer residuals. The Wald test statistic is $F(2,14-K-1)$ distributed. Benchmark assets are indicated by ' + '. Bold indicates that the hypothesis of mean-variance spanning cannot be rejected at a $1 \%$ level of significance. The estimated increase in expected return per unit of risk, $\Delta \sigma\left(m_{t+1}\right)$, is shown in parentheses.

Table 6a: Academic Abilities (Humanities)

\begin{tabular}{|c|c|c|c|c|c|c|c|c|c|c|}
\hline Additional assets & 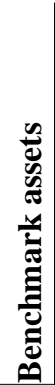 & 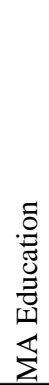 & 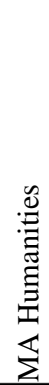 & 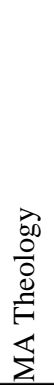 & 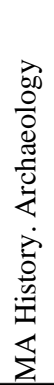 & 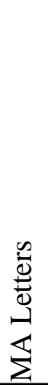 & 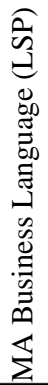 & 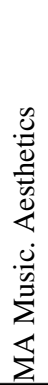 & p-value & $\Delta \sigma(\mathrm{m})$ \\
\hline MA Education & & & + & + & + & + & + & + & 0.67 & $(0.03)$ \\
\hline MA Humanities & & + & & + & + & + & + & + & 0.73 & $(2.29)$ \\
\hline MA Theology & & + & + & & + & + & + & + & 0.05 & $(6.88)$ \\
\hline MA History. Archaeology & & + & + & + & & + & + & + & 0.56 & $(2.11)$ \\
\hline MA Letters & & + & + & + & + & & + & + & 0.98 & $(0.09)$ \\
\hline MA Business Language (LSP) & & + & + & + & + & + & & + & 0.01 & $(4.13)$ \\
\hline MA Music. Aesthetics & & + & + & + & + & + & + & & 0.18 & $(2.43)$ \\
\hline
\end{tabular}


Table 6b: Academic Abilities (Natural Sciences)

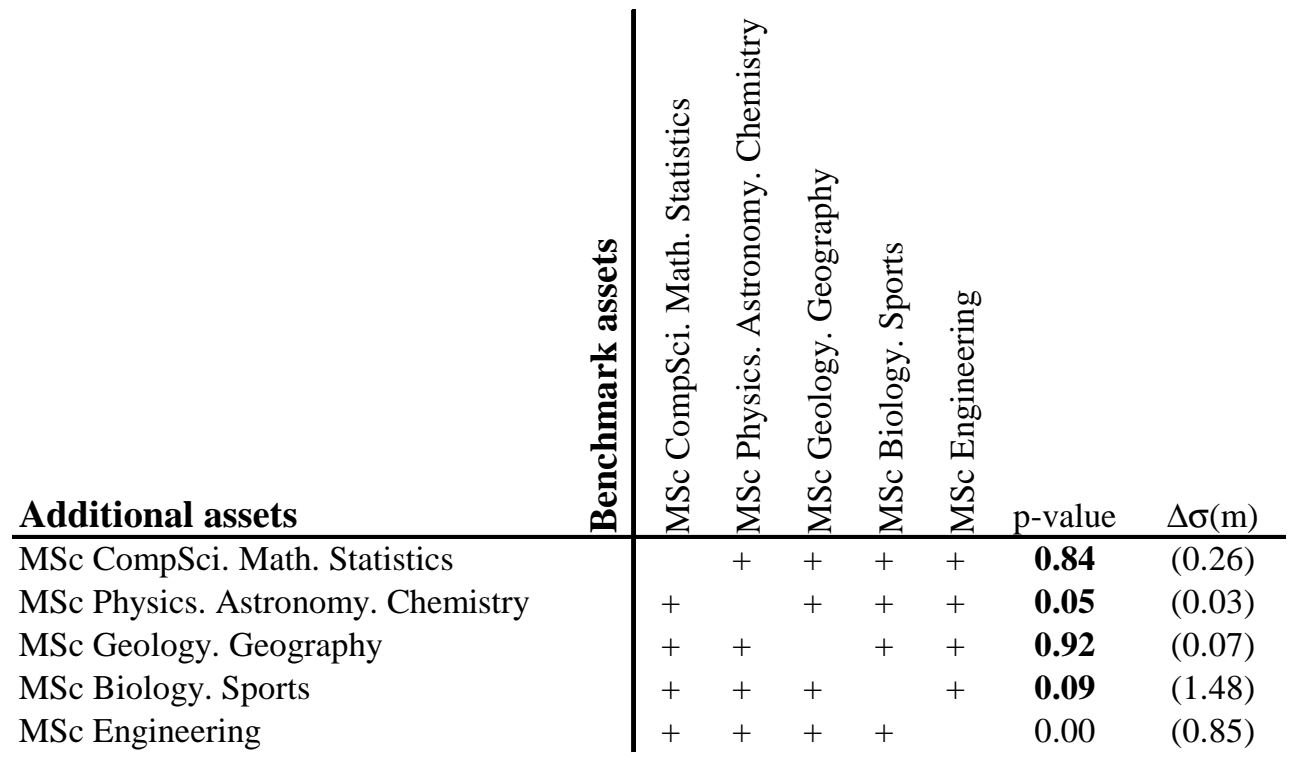

Table 6c: Academic Abilities (Social Sciences)

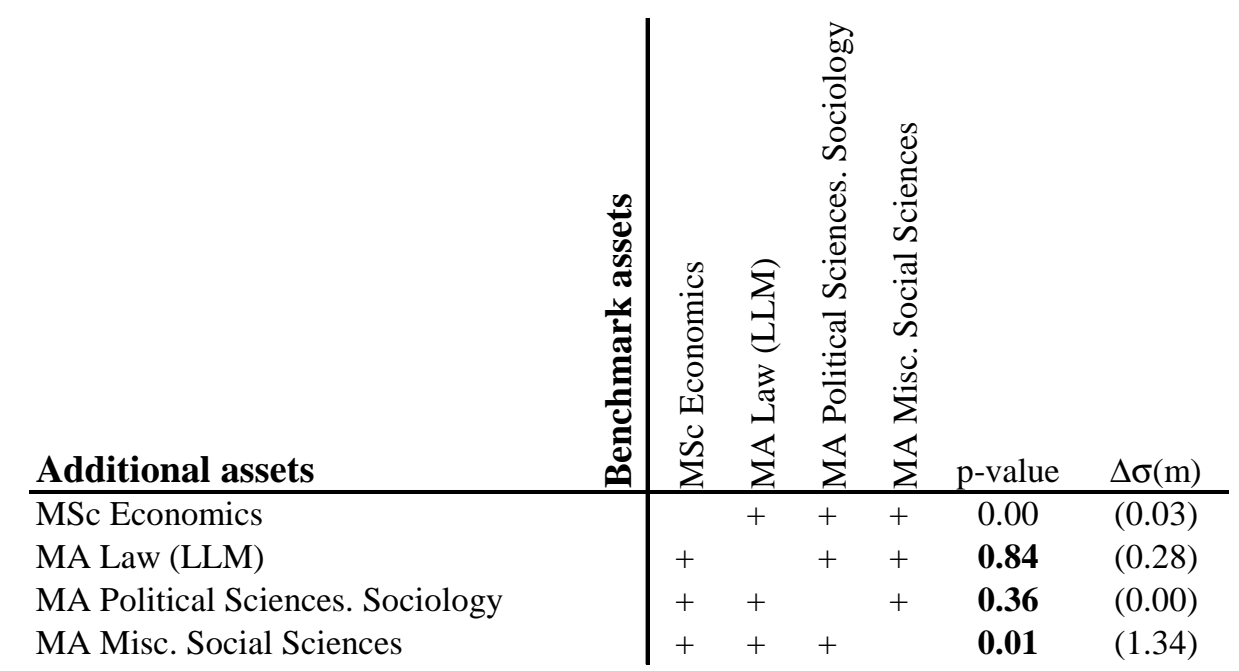


Table 6d: Academic Abilities (HealthCare Sciences)

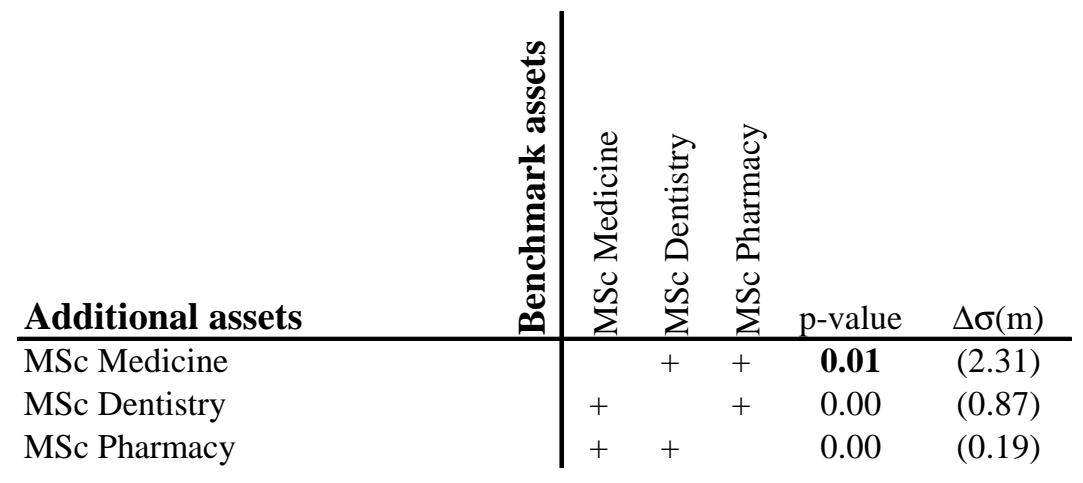

